\title{
LEADERSHIP IN PROJECT MANAGEMENT
}

A Thesis

Presented to

The Academic Faculty

by

Riyue Xiong

In Partial Fulfillment of the Requirements for the Degree

Master of Science in the

School of Architecture \& Building Construction Program

Georgia Institute of Technology

December 2008 


\section{LEADERSHIP IN PROJECT MANAGEMENT}

Approved by:

Professor. Kathy O. Roper, Advisor College of Architecture

Georgia Institute of Technology

Dr. Baabak Ashuri

College of Architecture

Georgia Institute of Technology

Dr. Linda Thomas-Mobley

College of Architecture

Georgia Institute of Technology

Date Approved: November 13th, 2008 
This research effort is dedicated to my family, in particular to my mother, LI Yun who has always stood by my side, encouraging and supporting me through the entire process. She talked to me when I faced some difficulties and almost gave up. She taught me hard work disciplines and made me continue my research and this also served me well in all aspect in my life. Additionally, I would like to dedicate this to my best friends, Ziming Zhao, Marianela Rivera, Yuan Cai. Thanks for being there whenever I need you. You are more than friends. You are my family! I offer special a thank you to each of you! 


\section{ACKNOWLEDGEMENTS}

I wish to express my deep appreciation to my advisor, Professor Kathy O. Roper,

for her continuous guidance, patience, encouragement, and helpful comments and suggestions throughout the whole research.

I would like to thank my thesis committee, Dr. Linda Thomas-Mobley and Dr. Baabak Ashuri for their constructive direction and insight.

I would like to thank all my co-workers in Skanska USA Building Inc. who provided precious information for my research and also their support and encouragement.

Finally, I would thank all of the individuals who participated in my research as interviewees. Without their help, I would never have completed this degree and this research project. 


\section{TABLE OF CONTENTS}

$\begin{array}{lr}\text { ACKNOWLEDGEMENTS } & \text { Page } \\ \text { LIST OF TABLES } & \text { iv } \\ \text { LIST OF FIGURES } & \text { vii } \\ \text { SUMMARY } & \text { ix } \\ 1 \text { INTRODUCTION } & 1\end{array}$

1.1 Project Management Overview 1

1.2 Background 3

$\begin{array}{ll}1.3 \text { Research Objectives } & 7\end{array}$

2 METHODOLOGY 10

2.1 Introduction $\quad 10$

$\begin{array}{ll}2.2 \text { Research Steps } & 10\end{array}$

2.2.1 Step One: Literature Review 10

2.2.2 Step Two: Interviews and Survey Results Analysis $\quad 11$

2.2.3 Step Three: Case Study 12

2.2.4 Step Four: Conclusions and Suggestions 12

3 LITERATURE REVIEW 13

3.1 Related Research 13

3.2 Concept of Project Leadership 14

3.3 Project Leadership Skills $\quad 15$

3.4 Leadership Theory 17 
3.4.2 Behavioral Approach 19

3.4.3 Situational Approaches to Leadership $\quad 20$

4 INTERVIEWS AND SURVEY RESULTS ANALYSIS 21

4.1 Survey Process 21

4.2 Data Collection and Basic Analysis 22

4.2.1 Role of Leadership in Project Success 22

4.2.2 Leadership Training 23

4.2.3 Levels of Leadership $\quad 24$

4.2.4 Job Satisfaction $\quad 26$

$\begin{array}{ll}\text { 4.2.5 Promotion } & 27\end{array}$

4.2.6 Team Members’ Participation 28

$\begin{array}{ll}\text { 4.2.7 Vision } & 30\end{array}$

4.2.8 Leadership Skills $\quad 32$

4.2.9 Characteristics of Good Leaders 34

4.2.10 Respondents’ Background 36

4.3 Results and Detailed Analysis 38

5 CASE STUDY 41

5.1 Introduction $\quad 41$

5.2 Skanska USA Building Case $\quad 41$

$\begin{array}{ll}\text { 5.2.1 Background } & 41\end{array}$

5.2.2 Leadership Theory 43

5.2.3 Leadership Training in Skanska 44 
6.1 Summary

APPENDIX A Survey: Leadership and the Project Management in Construction Field 51

APPENDIX B Survey Data Collection

APPENDIX E Percentage Changes in Producer Price Indexer for Contruction Material and Components, 2001-2008 


\section{LIST OF TABLES}

Page

Table 1.1: A Project Manager's Responsibilities

Table 4.1: Rank of Important Leadership Skills 


\section{LIST OF FIGURES}

Page

Figure 1.1: Change in Producer Prices for Construction vs. Consumer Prices 2

Figure 1.2: Frequently Encountered Problems in Project Management 7

Figure 1.3: Skills Needed to be a Successful Project Manager 9

Figure 3.1: Related Literature Research 13

Figure 3.2: Project Management Skills for Success 15

Figure 3.3: Relationships for Leadership Theory 17

Figure 4.1: Importance of Leadership Skills in Project Completion 22

Figure 4.2: Leadership Training Survey 23

Figure 4.3: Necessity of High Level Leadership Skills for Project Managers 24

Figure 4.4: Satisfication of Previous Work Exerience in Project 26

Figure 4.5: Relationship of Leadership Skills and Promotion 27

Figure 4.6: Necessity of Followers Participation in Decision Making Process 28

Figure 4.7: Importance of Followers Vision 30

Figure 4.8: Top Leadership Skills 32

Figure 4.9: Years of Experience of Respondents 34

Figure 4.10: Roles of the Respondents in Projects 34

Figure 4.11: Respondents’ Education Level 35

Figure 4.12: Resondents' Gender 35

Figure 5.1: Skanska's ISO-14001 Certification 40

Figure 5.2: Skanska Leadership Developments 43

Figure 5.3: Skanska's Management Development 44 


\section{SUMMARY}

The following thesis project addresses the importance and key role of leadership in project management, particularly in the construction field. Project management is a carefully planned and organized effort to accomplish a specific one-time task. For example, constructing a building or implementing a new computer system, all need to be well-managed. Projects are conceived and completed by people, who are involved in the whole process of project execution and completion. Thus, project management not only requires an efficient project manager, but also a qualified leader who can lead the team effectively.

A leader is someone who sets direction in an effort and influences people to follow that direction. It is important to have skills in forming, leading and facilitating a project team. However, a coherent theoretical foundation that explains how leadership engages people fully and effectively is lacking (Howell, 2006).

This research will provide a clearer understanding of the concept of leadership in projects, discussing how and why it works, and the ways to make project teams more dynamic and effective. The results from the study are applied to these leadership concepts, in an effort understand the role of effective leadership in reducing costs across the whole project process and increasing the project value.

This research includes four major steps. The first step is the general information collection, which provides a list of important leadership factors. Surveys and interviews are conducted in the second step, and the most significant factors are identified. The third step involves a case study, in order to demonstrate the importance of those factors and 
how they work in the real construction field. The case study selected is Skanska, a major international construction company. The internal management system, as well as the company's leadership philosophy and style, are presented. Projects completed by Skanska USA Building Inc. are analyzed to support this research. This study concludes with recommendations for future research. 


\section{CHAPTER 1}

\section{INTRODUCTION}

\subsection{Project Management Overview}

What is a project? According to the book, The Fast Forward MBA in Project Management, (Verzuh, 2008), all projects have two essential characteristics: 1) Every project has a beginning and an end; and 2) Every project produces a unique product.

With each project, unique tasks are completed in a specified period and contribute to the final result. In contrast, ongoing operations are continuous and do not have a designated end date of completion. People assigned to a specific project may come from different parts of an organization or even from outside the organization; after completion of the project, these people will go to other projects or back to the original functions in their organizations (Levy, 1994). In this case, project management will take on a different form than ordinary management, since each project has its own characteristics and features.

Project management is a relatively new concept. In the 1950s, a conscious effort was made to devise specialized tools for managing the complex weapon systems being built for the Department of Defense. These tools are now widely used in all industries, both public and private. Project management involves a methodological approach to planning and guiding project processes from start to finish. It is further defined as a carefully planned and organized effort to accomplish a specific one-time task, such as constructing a building or implementing a new computer system. Project management includes 
developing a project plan, which includes defining project goals and objectives, specifying tasks or how goals will be achieved, what resources are needed, and associating budgets and timelines for completion. Projects require project management and effective project management is important to all industries. According to a previous survey (Howard, 1999), project manager's responsibilities are diverse and include duties ranging from coordinating client and project team meetings to preparing budgets and negotiating contracts. Table 1.1 presents the results of a survey of 67 respondents denoting the importance of project managers' responsibilities 
Table 1.1 A Project Manager's Responsibilities (Project Management for Building Designers and Owners, 1999)

\begin{tabular}{|c|c|c|c|}
\hline Rank & Responsibility & Number' & Percent \\
\hline 1 & Consultant meetings/contact & 63 & 94.03 \\
\hline 2 & Project team meetings & 58 & 86.57 \\
\hline 3 & Client meetings/contact & 55 & 82.09 \\
\hline \multirow[t]{2}{*}{4} & Change order management & 54 & 80.60 \\
\hline & Project status reports (preparation or review) & 54 & 80.60 \\
\hline 6 & Personnel plamning & 52 & 77.61 \\
\hline 7 & Scope determination & 49 & 73.13 \\
\hline \multirow[t]{3}{*}{8} & Quality assurance & 48 & 71.64 \\
\hline & Quality control & 48 & 71.64 \\
\hline & Consultant expense review or approval & 48 & 71.64 \\
\hline \multirow[t]{2}{*}{11} & Project budget preparation & 47 & 70.15 \\
\hline & Billing preparation, review, and/or collection & 47 & 70.15 \\
\hline \multirow[t]{4}{*}{13} & Developing a project checklist & 45 & 67.16 \\
\hline & On-site observation & 45 & 67.16 \\
\hline & Construction administration management & 45 & 67.16 \\
\hline & Selection of consultants & 45 & 67.16 \\
\hline \multirow[t]{2}{*}{17} & Project close-out/evaluation & 43 & 64.18 \\
\hline & Proposal preparation & 43 & 64.18 \\
\hline \multirow[t]{2}{*}{19} & Specification preparation/review & 42 & 6269 \\
\hline & Payment application review and processing & 42 & 62.69 \\
\hline 21 & Selection of project team members & 41 & 61.19 \\
\hline 22 & Vendor expense review or approval & 40 & 59.70 \\
\hline 23 & Submittal review and processing & 39 & 58.21 \\
\hline \multirow[t]{2}{*}{24} & Negotiating desigruer/owner contracts & 36 & 53.73 \\
\hline & Negotiating designer/consultant contracts & 36 & 53.73 \\
\hline 26 & Marketing & 35 & 52.24 \\
\hline \multirow[t]{2}{*}{27} & Construction cost estimating & 34 & 50.75 \\
\hline & Construction cost control & 34 & 50.75 \\
\hline 29 & Partnering process participation & 32 & 47.76 \\
\hline 30 & Program preparation & 29 & 43.28 \\
\hline 31 & Project follow-up/post-occupancy evaluation & 28 & 41.79 \\
\hline 32 & Time-card approval/teview & 25 & 37.31 \\
\hline 33 & Site selection & 10 & 14.93 \\
\hline 34 & Land acquisition & 8 & 11.94 \\
\hline 35 & Firancing negotiation. & 6 & 8.96 \\
\hline 36 & Other & 3 & 4.48 \\
\hline
\end{tabular}

\subsection{Background}

The construction industry is a major global business, and plays an essential role in sustaining economic growth, in addition to producing structures that add to productivity 
and quality of life. In the United States, this industry employs more than 7.3 million onsite workers and accounts for about 8.4 percent of the entire country's gross domestic product (GDP), totaling $\$ 1.16$ trillion in 2007. This does not include the value of building supplies and equipment, such as steel, concrete and lumber. According to data from the Associated General Contractors of America (AGC), the leading national construction trade association representing both the public and private sectors, for each dollar spent on new construction, a total of $\$ 11$ in economic activity is generated across all industries and other services. Since December 2003, the cumulative increase in the prices of inputs used in construction (45\%) has been more than double the increase in the consumer price index (19\%), as shown in Figure 1.1. Given the worldwide competition, it appears prudent to expect construction input prices to rise 6 to 8 percent a year for the next several years (AGC, 2008). 


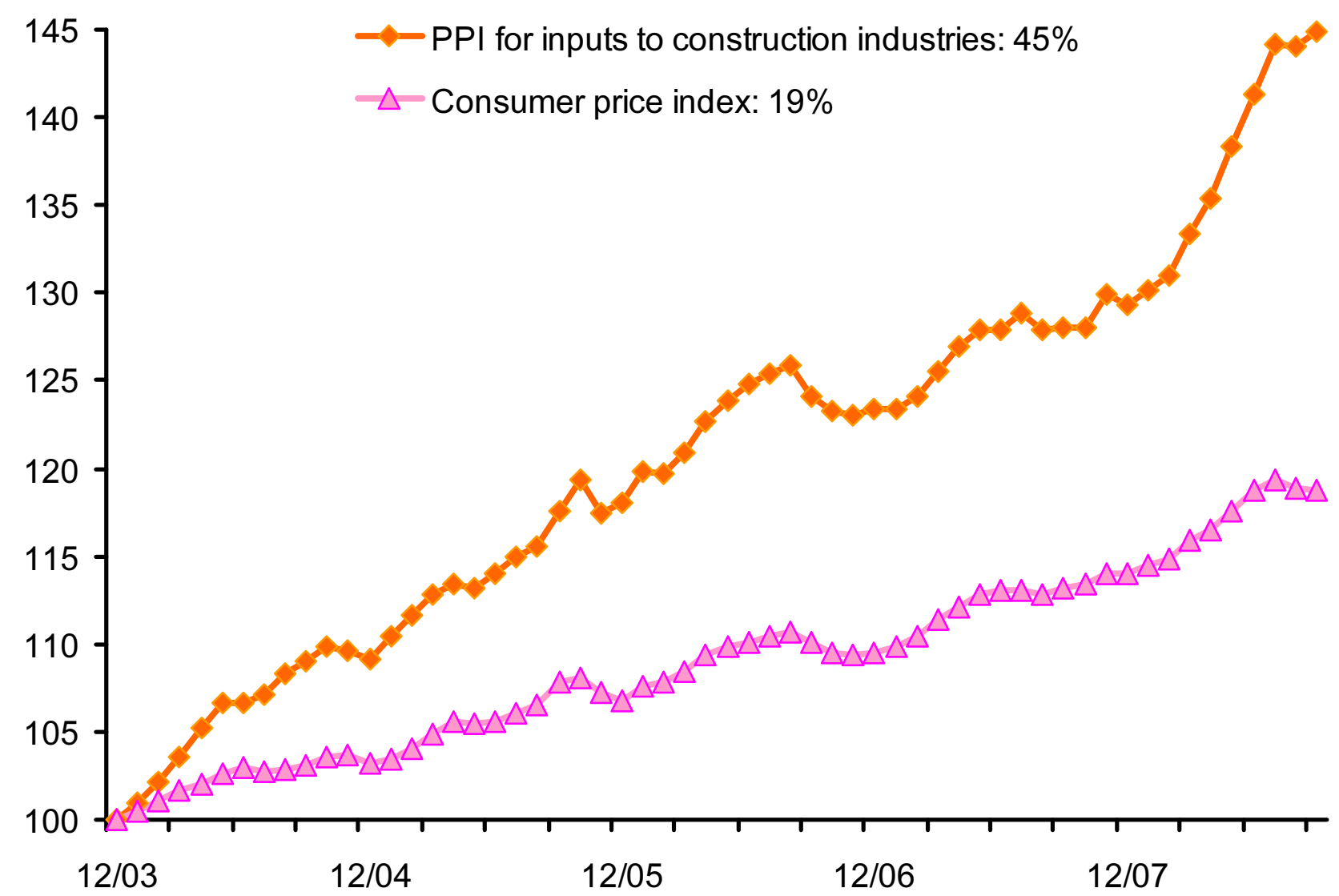

Figure 1.1 Change in Producer Prices for Construction vs. Consumer Prices, 2003 - 2008 (December $2003=100$ )

(Source: BLS (CPI, PPI), Associated General Contractors of America, 2007)

Former Assistant Secretary of the Army Robert W. Paige stated (Levy, 1994) the importance of project management in construction industry several years ago:

Every time this industry has failed, it's because of bad management. Every company that failed was managed badly. I don't know why we don't emphasize that, it's extremely important. You've got to start training people in college to at least begin thinking about management. And when they get out they have to understand that there's a bigger deal out there that just engineering or building. They must understand that they are going to a business. They will be part of the largest damn private sector business in the United States. Somebody has to manage it.

The increase in global competition and the extraordinary growth in construction and facilities have created other problems for project managers. Figure 1.2 shows the most frequently encountered problems in project management. 


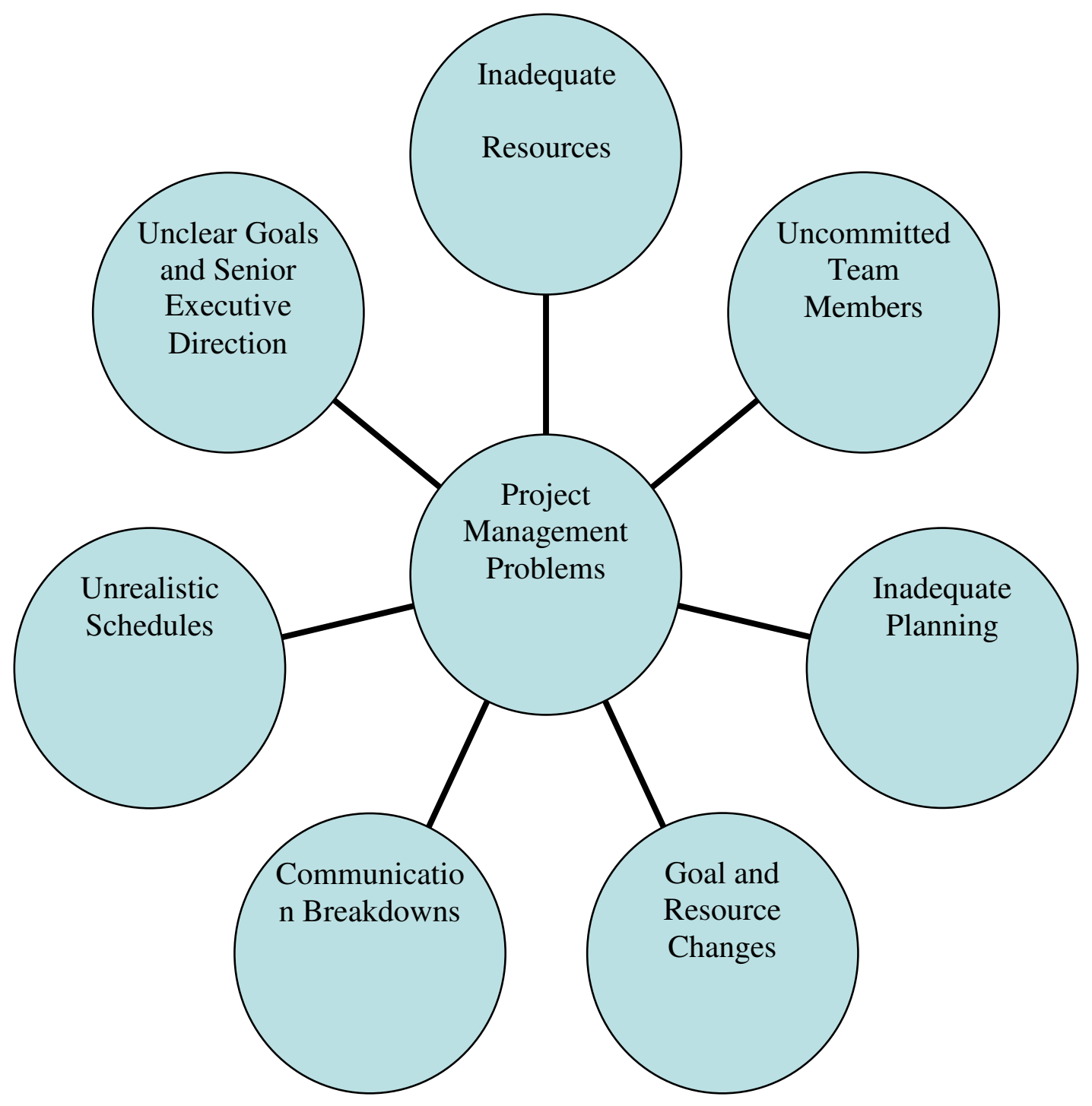

Figure 1.2 Frequently Encountered Problems in Project Management (Source: "A Survival Guide for Project Management", 2006)

Given the types of problems facing project managers, the question involves how to solve these problems, and how to obtain the knowledge and skills needed to solve them. Because of the global economic impact the construction industry has, this issue of effective project management is of critical importance. 
The Project Management Institute (PMI) membership of professional project managers identifies a body of knowledge, known as the Project Management Body of Knowledge (PMBOK). The following nine areas describe project management's knowledge and practice (PMBOK, 2004):

1. Integration Management.

2. Scope Management.

3. Time Management.

4. Cost Management.

5. Quality Management.

6. Human Resources Management.

7. Communication Management.

8. Risk Management.

9. Procurement Management.

\subsection{Research Objectives}

Today, many people believe that as long as a person has strong technical skills, demonstrated a certain amount of aggressiveness and enthusiasm, and has worked on several project teams, he or she could be given the role of project manager. However, project managers can no longer depend on their positions or their own personal initiative to accomplish a goal because most projects managed today are from a matrix organization, in which project managers do not have complete authority over team members. Given these challenges, the question is: What kind of skills can make a difference in successfully managing a project and which are the most important ones? 
Figure 1.3 shows six categories which are considered to be the most important skills in project management.
1. Communication Skills
Listening
Persuading
2. Organizational Skills
Planning
Goal Setting
Analyzing
3. Team-Building Skills
Empathy
Motivation
Esprit de Corps
Creativity

\section{Leadership Skills \\ Sets Example \\ Energetic}
Vision (sees the big picture)
Delegates
Positive Attitude
5. Coping Skills
Flexibility
Creativity
Patience
Persistence
6. Technological Skills
Experience
Project Knowledge

Figure 1.3 Skills Needed to be a Successful Project Manager (Tayler, 2006)

As shown in Figure 1.3, one of the most important skills needed for effective project management is leadership. Therefore, the objectives of my research are:

1. Provide a clear understanding of the concept of leadership in project management.

2. Determine the most important leadership skills that project managers should have. 
3. Demonstrate how to use leadership skills to deal with problems in real construction industry practices.

4. Give suggestions on how to gain leadership skills. 


\section{CHAPTER 2}

\section{METHODOLOGY}

\subsection{Introduction}

This research includes four major steps. The first step involves general information collection, including both first-hand and second-hand data, in order to identify major themes from the literature. Surveys and interviews are conducted, in which a list of important factors in successful leadership are identified. With these factors, expert interviews, conducted in the second step, are used to decide the most significant factors among them. The third step is the case study to show the importance of those factors and how they work in the construction field. The last step is the conclusions and suggestions for researchers or practitioners.

\subsection{Research Steps}

\subsubsection{Step One: Literature Review}

The literature review is the first step in this research. The intent is to collect enough evidence to validate a theory and apply the theory to the real world. Data evidence and figures included in this research are from both direct and indirect resources. First-hand data from survey and interviews and second-hand information from academic books and journals are the two main sources for this research. 


\subsubsection{Step Two: Interviews and Survey Results Analysis}

During this process, a survey for leadership in project management is designed and sent via e-mail; telephone interviews are also conducted. After the response period ended, the data and statistics are collected, reduced and analyzed. For some of the surveys, several respondents did not reply or answered less than half of the questions. Those responses are reduced from the data, in order to maintain the authenticity and accuracy of the survey data. Then key leadership skills are introduced and generalized in a list for reference purposes.

After the general data and statistics information collection, interviews with experts in project management are conducted. Some of the interviewees are project managers in construction industry, and others are university-based scholars. Interviewees are selected from both the United States and China, in order to provide multiple perspectives and more comprehensive results. Respondents are asked several directed questions and also provided their own opinions concerning leadership skills in project management. Some interviewees are non-English speakers; the researcher translated the questions and responses.

One more thing to mention before making conclusions, it is a perception - based survey, which some questions were designed according to the researcher's assumptions. Limitations exist in the survey results. Therefore, the next step was processed which fulfill the research. 


\subsubsection{Step Three: Case Study}

A case study is a way to test the applicability of a theory using real-world evidence. The intent is not necessarily to select a successful or unsuccessful example, but rather to demonstrate that leadership is a key element in project management, and a project cannot succeed without it. The selected case is tested in this step, with the purpose of showing how leadership skills affect projects. The case study selected is Skanska, a major international construction company. The internal management system, as well as the company's leadership philosophy and style demonstrated during each construction project, are presented. Projects completed by Skanska USA Building Inc. are analyzed.

\subsubsection{Step Four: Conclusions and Suggestions}

In the final step of the research, conclusions are drawn and suggestions are provided to assist researchers or practitioners who wish to become successful leaders. However, given the uniqueness of individuals, some parts of this research may not be applicable. The main purpose of this research is to provide suggestions for general construction projects. 


\section{CHAPTER 3}

\section{LITERATURE REVIEW}

\subsection{Related Research}

In this step of the research methodology, a comprehensive literature review of leadership skills is conducted. Literature on leadership skills are divided into four parts, including: the concept of project leadership; literature directly related to leadership skills; organizational performance; and leadership characteristics, traits and behavior. Figure 3.1 shows the subdivision of topics for the literature review.

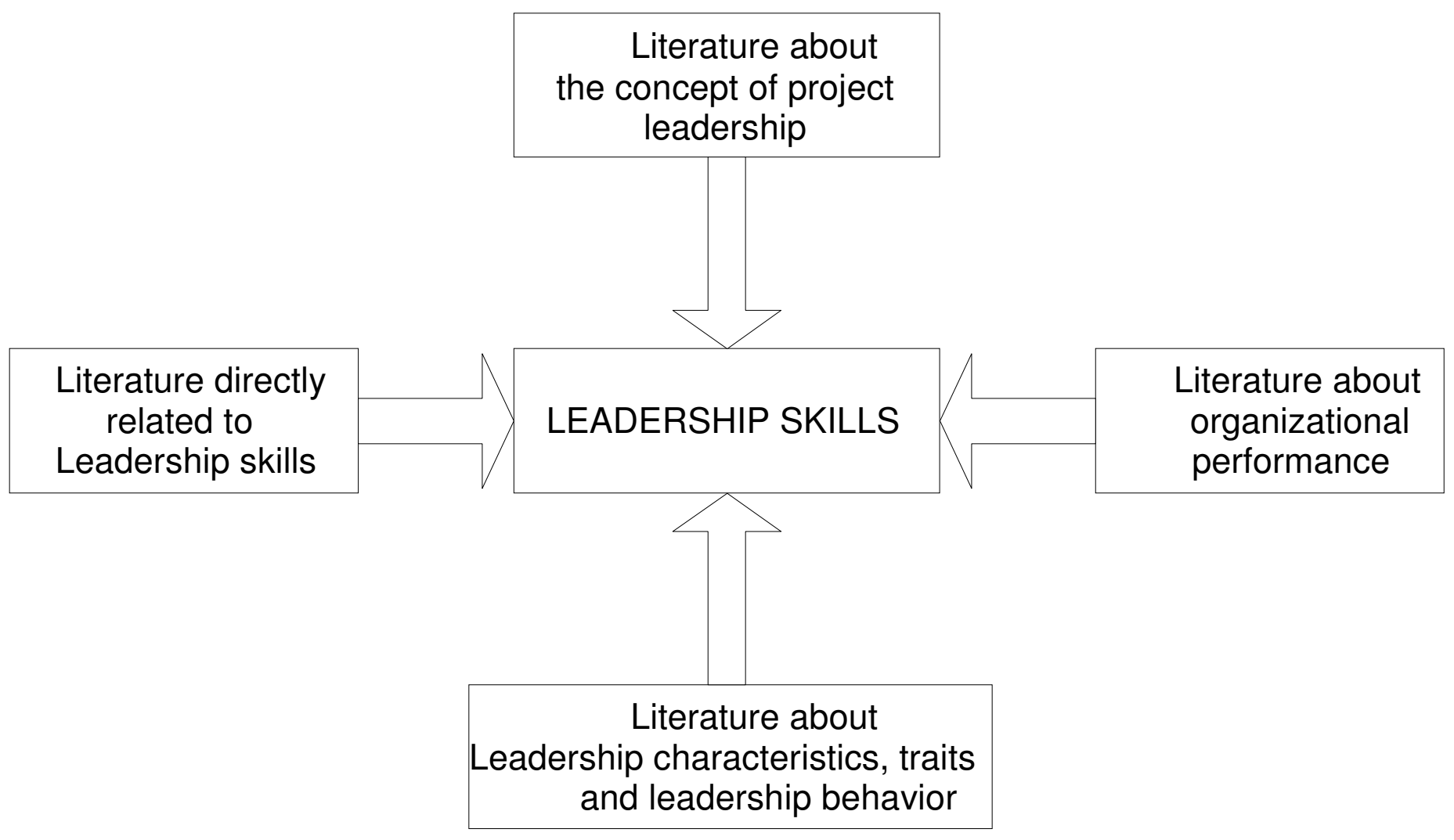

Figure 3.1 Related Literature Research 


\subsection{Concept of Project Leadership}

Leadership is one of the most important and essential factors in good project management. Leadership can be seen as the art of influencing others to achieve desired results. Leaders guide behaviors by setting the vision, direction and the key processes; in other words, leadership has a large influence on the whole project process, including the actions of others.

Jack Welch, previous CEO of General Electric, is reported to have called his direct reports together one day and issued a three word dictum: "Don't manage! Lead!'(Slater, 1998). The emphasis in the project management field on leadership as opposed to management is in recognition of the need for the special skill sets that leaders posses and bring to an organization or project. Many administrators, supervisors, and even top executives execute their responsibilities without being great leaders. While many managers focus on superficial activities and worry about short-term profits and stock prices, few have emerged as leaders who foster innovation and the attainment of long-term goals. Whereas many managers are overly concerned with maintaining the status quo, those who emerge as leaders are more concerned with making important decisions, even if they are unpopular. This trend toward leadership in project management is shown in Figure 3.2 below. Among all the skills in project management, the leadership skill component is one of the significant values in the present, and is predicted to be become more important in the near future. 

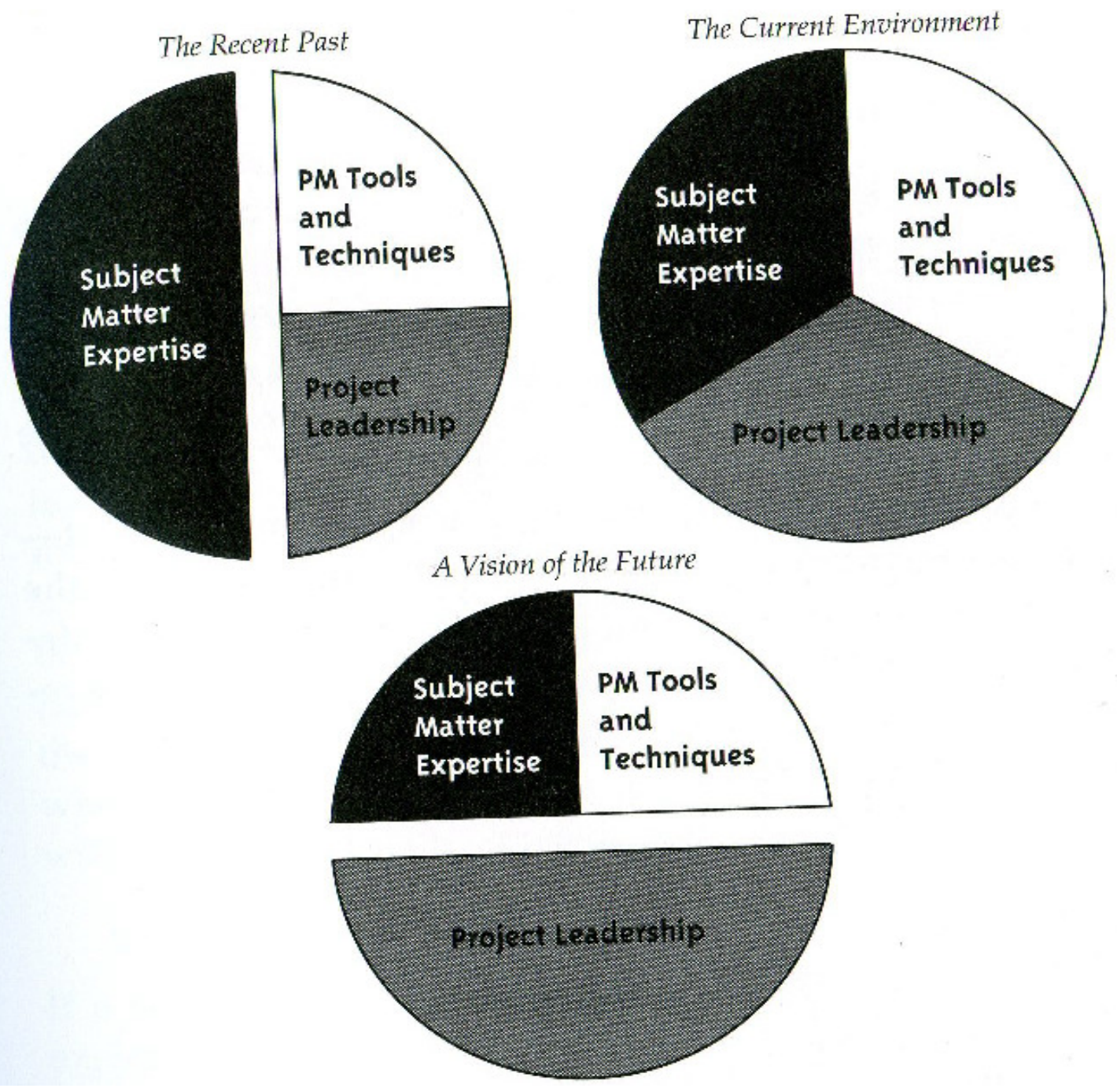

Figure 3.2 Project Management Skills for Success (Richman, 2006)

\subsection{Project Leadership Skills}

A leader is a person who sees something that needs to be done, knows that they can help make it happen, and gets started. Definitions of good leadership have varied; Kevin (2007) identifies a number of characteristics that make a successful leader, as listed below: 
- A leader sees opportunity and captures it.

- A leader sees a future that can be different and better, and helps others see that picture too.

- A leader knows they can't do it alone.

- A leader is a coach.

- A leader is an encourager.

- A leader views change as their ally.

- A leader is willing to take risks today for something better tomorrow.

- A leader is a learner.

- A leader is a communicator.

- A leader is a coordinator.

- A leader is a listener.

- A leader takes a long view - letting their vision keep their daily steps on track.

- A leader is passionate.

- A leader motivates and inspires.

- A leader values results.

- A leader cares about more than results though; she cares about those who are following her lead.

- A leader makes a difference in the lives of others.

- A leader is all of these things and much more. (Eikenberry, 2007)

As stated by John F. Kennedy, in a speech in Dallas: "Leadership and learning are indispensable to each other." (Kennedy, 1963) This statement is particularly applicable in 
the field of project management. Most individuals are not born with all the skills needs to be successful leaders; rather, leadership skills are learned and accumulated over time. Most frequently, there are three ways in which individuals can gain knowledge about leadership and develop leadership skills: from personal experience; examples and cases from others' experience; and books or related materials.

There are a number of studies on the development of leadership skills. From the review of the literature, there are 11 most commonly identified skills that are characteristic of strong leaders. These skills include: Understanding the needs and characteristics of the post; Communicating; Knowing and using the resources of the group; Planning; Controlling group performance; Setting the example; Sharing leadership; Counseling; Evaluating; Effective teaching; and Representing the group. These skills will be discussed and selected in the following survey.

\subsection{Leadership Theory}

Leadership theory can be categorized into three areas: trait-based, situational, and a behavioral approach. These three categories are traditional approaches to understanding leadership. The relationships between them are shown in Figure 3.3 below. 


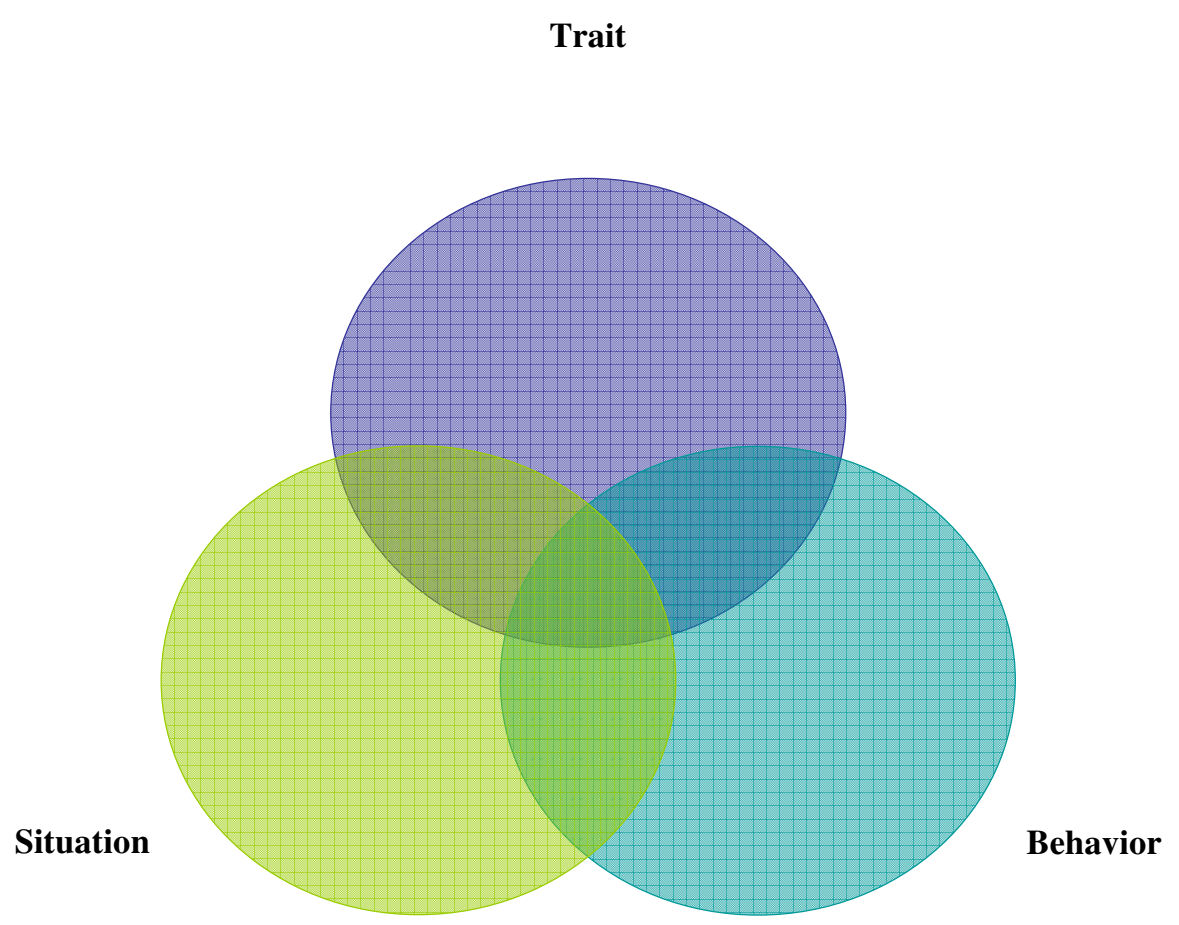

Figure 3.3 Relationships for Leadership Theory (Richman, 2006)

\subsubsection{Trait Approach}

Trait theories are leadership perspectives that focus on individual leaders and attempt to determine the personal characteristics that great leaders share. These are all traits that someone can learn to implement with practice, over time. The character traits associated with leadership are identified as the following:

1. Enterprising Spirit: Enterprising spirit refers to a set of characteristics that reflect a high level of effort. It includes high demand for achievement, constant striving for improvement, ambition, energy, tenacity, and initiative. 
2. Loyalty: Leaders who demonstrate loyalty and honesty, and are willing to admit to mistakes, display key traits that followers look for in their leaders. A leader will also increase their influence when people trust and believe his or her loyalty.

3. Leadership Motivation: Great leaders not only have an enterprising spirit, but they also want to lead. They have a high desire for power, preferring to be in position of leadership rather than that of a follower.

4. Integrity: Integrity is measured by an individual's actions and words. People who do not perform and do not execute what they promised are not considered good leader.

5. Self-confidence: Self-confidence is important for a number of reasons. The leadership role is challenging, and setbacks are inevitable. Self-confidence allows a leader to overcome obstacles, make decisions despite uncertainty, and instill confidence in others.

6. Knowledge: Effective leaders have a high level of knowledge about their industries, companies, and technical matters. Leaders must have the intelligence to interpret vast quantities of information.

In addition to the traits mentioned above, there are other characteristics which have a significant influence on leadership, including being forward-looking, competent, inspiring, and intelligent.

\subsubsection{Behavioral Approach}

Behavioral theories of leadership do not focus on inborn traits or capabilities; rather, the focus is on what leaders actually do. Three general categories of leadership behaviors are mentioned frequently in the literature: behaviors related to task 
performance; behaviors related to group maintenance, and behaviors related to employee participation in decision-making.

1. Task Performance Behaviors: Task performance behaviors are the leader's efforts to ensure that the teams or organizations reach their goals. Those behaviors include a focus on work efficiency, quality and accuracy, quantity of output, and adherence to regulations.

2. Group Maintenance Behaviors: These actions are taken to ensure the satisfaction of group members, develop and maintain harmonious work relationships, and preserve the social stability of the group, focusing on people's feelings and comfort, appreciation, and stress reduction.

3. Participation in Decision-Making: This behavior appears during the process of making decisions, in which leaders can range from autocratic to democratic. Autocratic leadership is a form of leadership in which the leader makes decisions on his or her own and then announces those decisions to the group; democratic leadership is a form of leadership in which the leader solicits input from subordinates. Studies of how the leader's behavior influences employee attitudes and performance have focused on autocratic versus democratic decision styles, or on performance- versus maintenance-oriented behaviors.

\subsubsection{Situational Approaches to Leadership}

Situational theories distinguish leaders from others through the situation at-hand. Leaders adjust their decision-making, orientation, and motivational approaches based upon a unique combination of factors in their individual situations. These factors include: characteristics of followers; types of projects; organizational structures; personal preferences; and upper-level management's influences. Leaders adjust their style of management in order to accommodate the different situations. 


\section{CHAPTER 4}

\section{INTERVIEWS AND SURVEY RESULTS}

\section{ANALYSIS}

\subsection{Survey Process}

The survey is designed to solicit input from those in the field of construction and project management concerning leadership and the leadership skills. Questions centered on the importance of leadership, the kinds of leadership skills people should pursue, and the most-commonly used skills. A common survey process includes defining the survey objectives, developing a sample frame, specifying the strategy for data collection, and conducting the appropriate analyses. Interviewees are selected from the construction or relevant project management field and all have certain knowledge or experience in project management. The interviewees include project managers in large construction companies (including Skanska, Turner, and Parsons and some other construction companies), researchers, and university professors. Surveys are sent via e-mail; several telephone and in-person interviews are also conducted. The total number of responses for this survey is 69 out of 200 . The response rate is $34.5 \%$ which is acceptable, according to a previous research on survey results analysis. (Sheehan, 2001)

- Mail: $50 \%$ adequate, $60 \%$ good, $70 \%$ very good

- Phone: $80 \%$ good

- Email and Online: $30 \%$ average, $45 \%$ good, $60 \%$ very good

- Classroom paper: $>50 \%=$ good

- Face-to-face: $80-85 \%$ good 
The formal survey questions and details are attached as Appendices A and B.

\subsection{Data Collection and Basic Analysis}

The first two steps for a formal survey process are defining the survey objectives and determining who will be sampled. The participants are pre-selected and, thus, the response rate and the accuracy are expected to be high. There are 13 total questions included on the survey. For several of the questions, respondents are asked to state whether they agree or disagree with a particular statement; other questions are designed to solicit input with regard to identifying key leadership skills. The following describes the questions asked in the survey and includes an analysis of the data.

\subsubsection{Role of Leadership in Project Success}

Leadership is a significant factor in the whole project process, and the importance of leadership is growing with the increasing quantities of global projects. As people from across the globe work collaboratively on meeting project goals, leadership and a good team environment are needed for success. Respondents are asked to assess the importance of leadership in the following survey question:

Question 1: Leadership is necessary in completing projects successfully.

Respondents are asked whether they agree, partially agree, disagree or have no opinion on the above statement. Results are shown in Figure 4.1. 


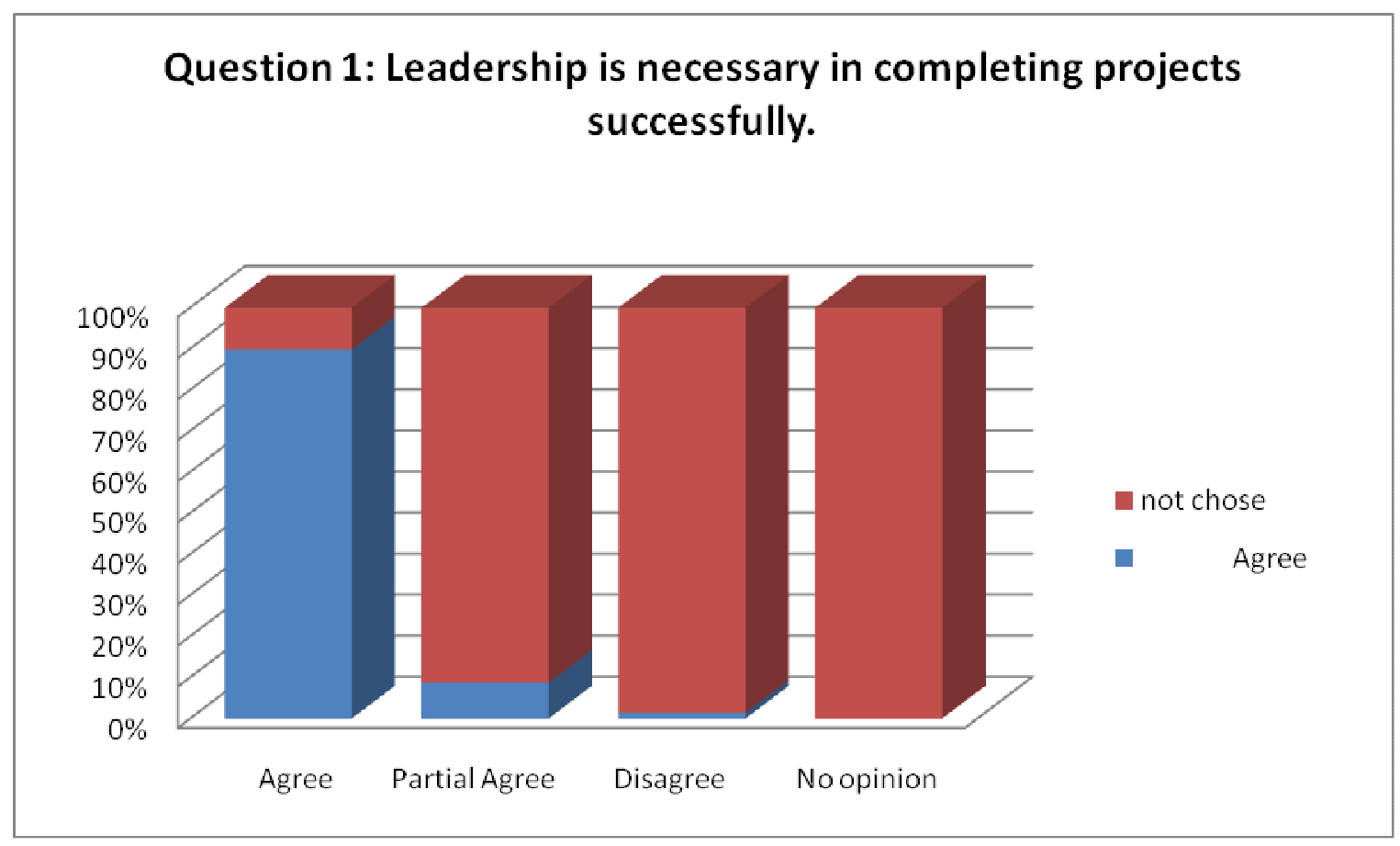

Figure 4.1: Importance of Leadership Skills in Project Completion

According to the survey, $62(90 \%)$ interviewees agree, $6(9 \%)$ partially agree and only one (1\%) disagrees with this statement; thus, the majority of respondents believe or partial beliveve that leadership is necessary and a key factor of success in project management.

\subsubsection{Leadership Training}

There is some disagreement concerning whether formal training is required for individuals to be successful leaders. Some argue that leadership skills are gained through daily life and practical experience or that some individuals are naturally born leaders, and, thus, no formal training is required. Others argue that formal training is a requirement to successful leadership, particularly as projects and problems grow in complexity. The following question asks respondents to state their opinions regarding the link between formal training and successful project managers: 
Question 2: It is important for a leader to have formal leadership training to be successful.

Respondents are asked whether they agree, partially agree, disagree or have no opinion on the above statement. Results are shown in Figure 4.2.

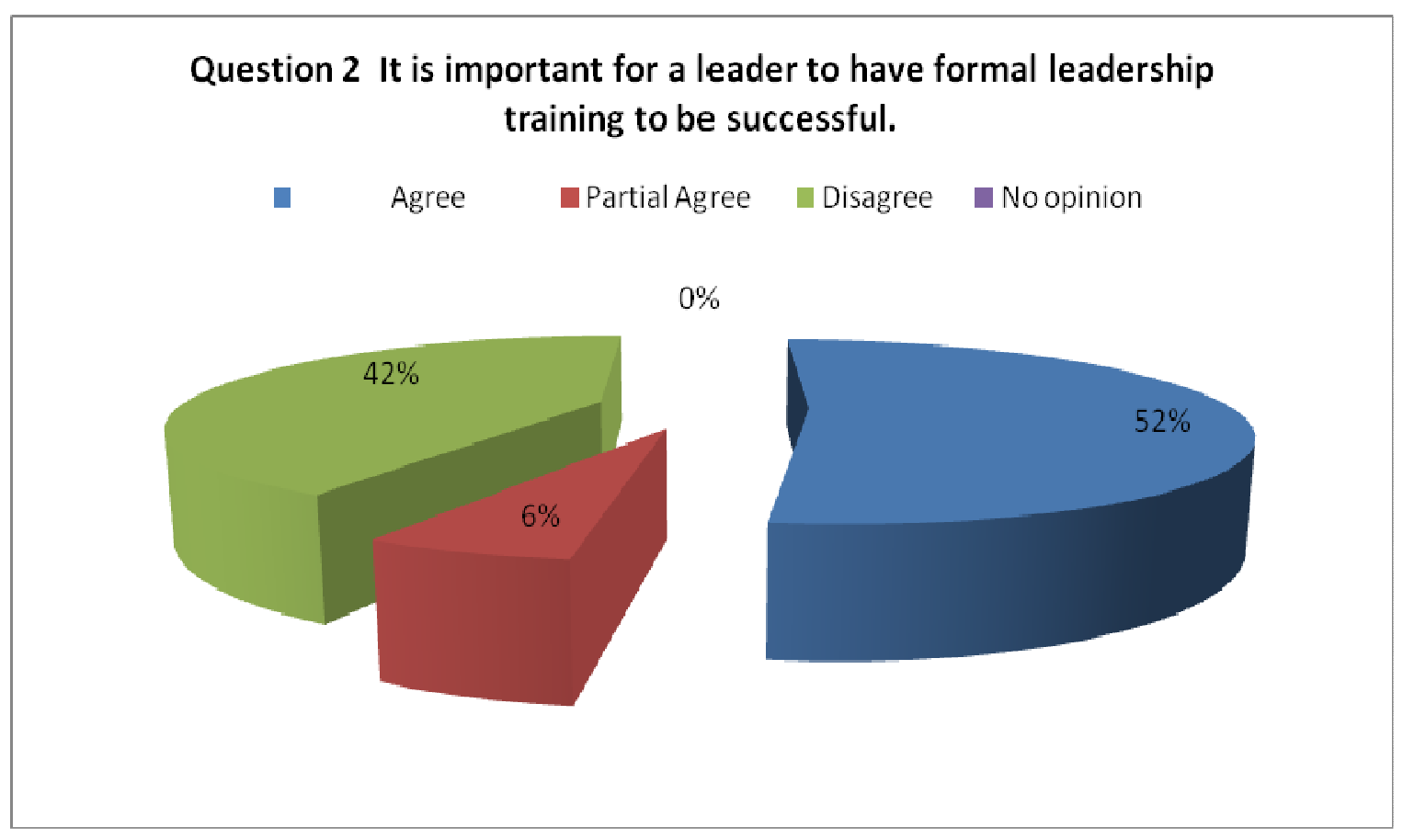

Figure 4.2: Leadership Training Survey

According to the survey, although there are a large number of respondents who do not think training is important, more than half of the interviewees believe that leadership training is important and necessary for people who want to become a successful leader.

\subsubsection{Levels of Leadership}

Respondents are asked to state their opinions regarding the connection between successful project managers and leadership skills:

Question 3: I feel that successful project managers have high-level leadership skills. 
Respondents are asked whether they agree, partially agree, disagree or have no opinion on the above statement. Results are shown in Figure 4.3.

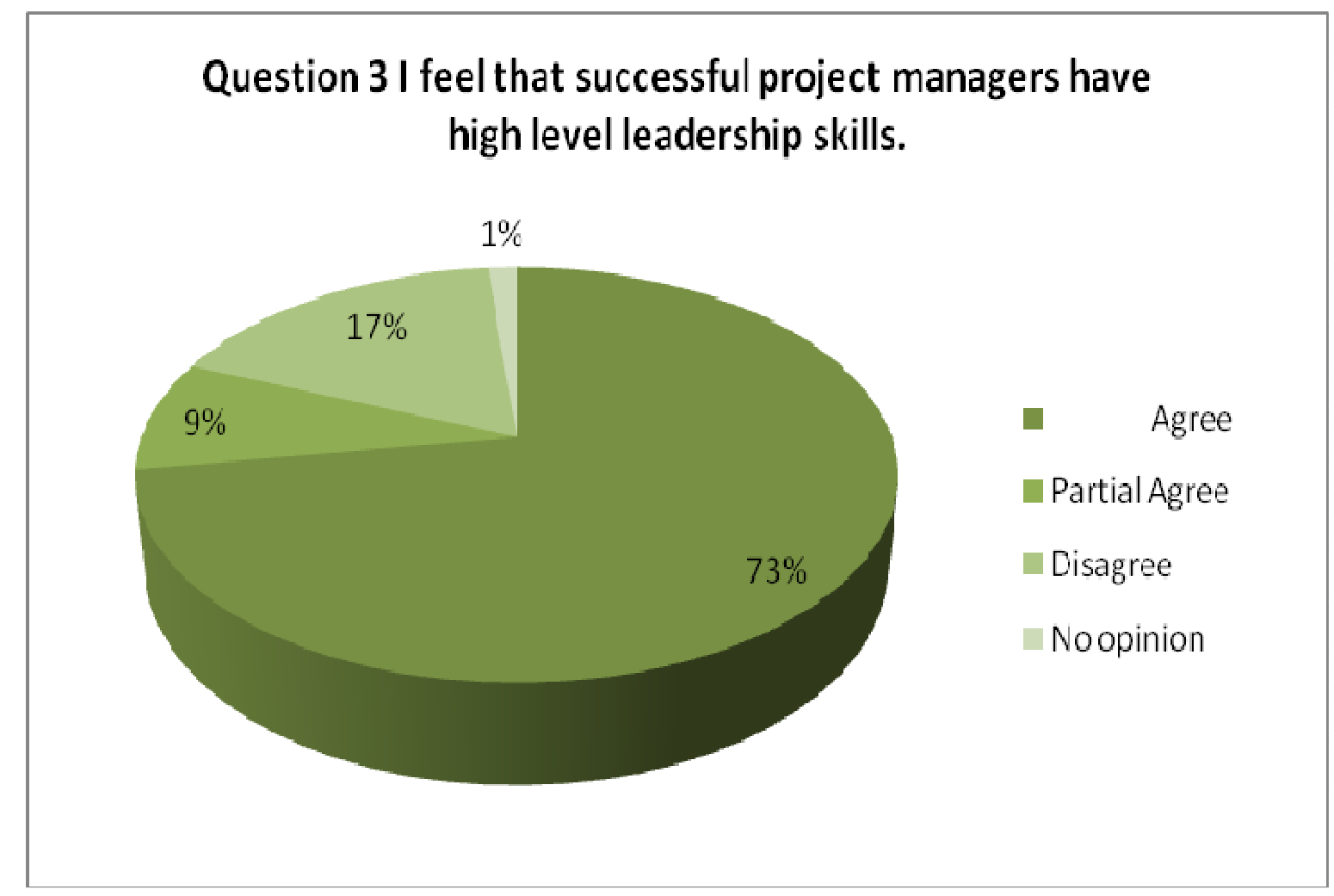

Figure 4.3: Necessity of High Level Leadership Skills for Project Managers

Of the respondents, $73 \%$ people in the survey believe successful project managers have a high level of leadership skills and $9 \%$ partial agree with that statement, for a total of $82 \%$. Leadership skills can help people run a project more easily, but they are not guarantees of project success. While project managers might be successful with leadership skills, they will definitely fail without those skills. In some cases, projects may be completed by a leader with low-level skills; however, if this leader could acquire more skills, the project may be more successful in some aspects. For example, the project may have greater time-savings, reduced total costs or lead to greater profit. 


\subsubsection{Job Satisfaction}

Question 4 addresses the project manager's performance in the real world, and how the application of leadership skills, in turn affects the job satisfaction of team members. Respondents are asked to provide their opinion of the following statement:

Question 4: I feel extremely satisfied with my job when working for a project manager.

Respondents are asked whether they agree, partially agree, disagree or have no opinion on the above statement. Results are shown in Figure 4.4.

\section{Question 4. I feel extremely satisfied with my job when working for a project manager.}

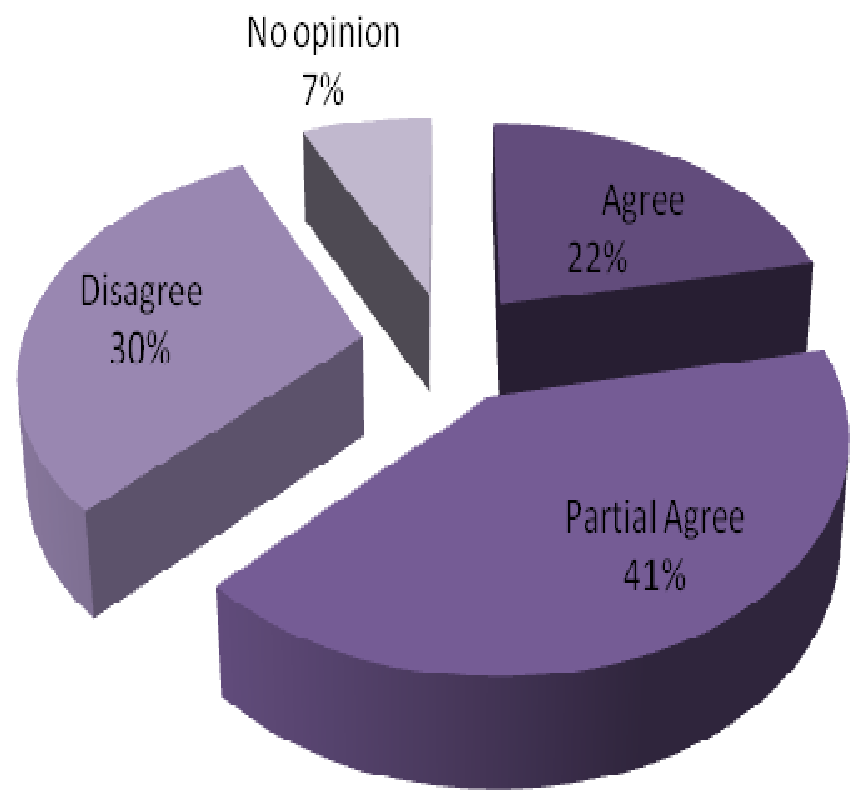

Figure 4.4: Satisfication of Previous Work Exerience in a Project 
According to the survey, only $22 \%$ of people are really satisfied with their project managers, while $30 \%$ of the interviewees are not satisfied. There may be several reasons for this level of dissatisfaction. As mentioned before, a good leader is supposed to be respected by his or her followers. However, the reality is that almost two thirds of the project managers are not considered successful leaders. While they may be able to complete a project, they may not inspire faith or confidence in their abilities from their subordinates. This may stem from a lack of leadership skills. While project managers may be well-intentioned, their subordinates may not convinced by their actions. This phenomenon is commonplace in the construction industry, according to this survey. On the other hand, the result can be interpreted in support of the results from Questions 1 and 2, concerning the importance of leadership the need for formal leadership training.

\subsubsection{Promotion}

The connection between leadership and career advancement is the subject of Question 5. Survey participants are asked for their opinion on the following question:

Question 5: I feel that it is important for someone to demonstrate leadership in order to be promoted to a leadership position.

Respondents are asked whether they agree, partially agree, disagree or have no opinion on the above statement. Results are shown in Figure 4.5. 


\section{Question 5 I feel that it is important for someone to demonstrate leadership in order to be promoted to a leadership position.}

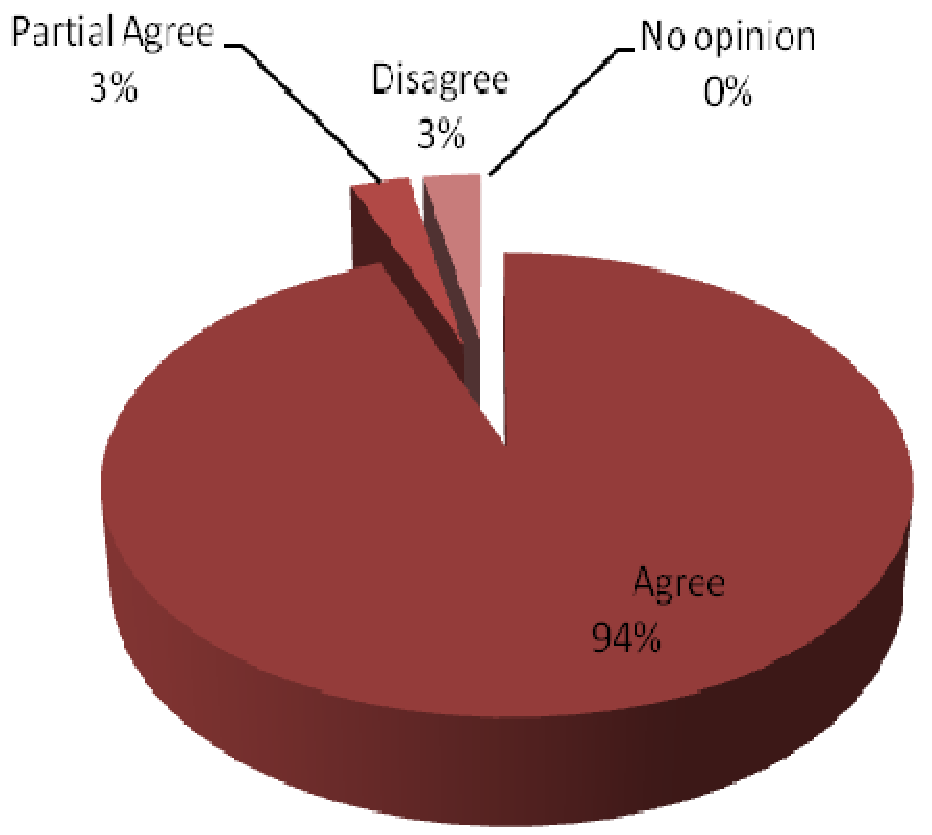

Figure 4.5: Relationship of Leadership Skills and Promotion

Nearly all respondents agree that leadership skills play an important role in career promotion, further demonstrating the significance of quality leadership. However, in order to achieve this goal, people may need leadership training, or may need to acquire these skills on their own, in order to advance their career.

\subsubsection{Team Members' Participation}

Question 6 focuses on the project team members' participation in the decisionmaking process. Respondents are asked to provide their level of agreement with the following statement: 
Question 6: I feel that it is best to create an environment where the team members take ownership of the project. Everyone should participate in the decision-making process.

Respondents are asked whether they agree, partially agree, disagree or have no opinion on the above statement. Results are shown in Figures 4.6.

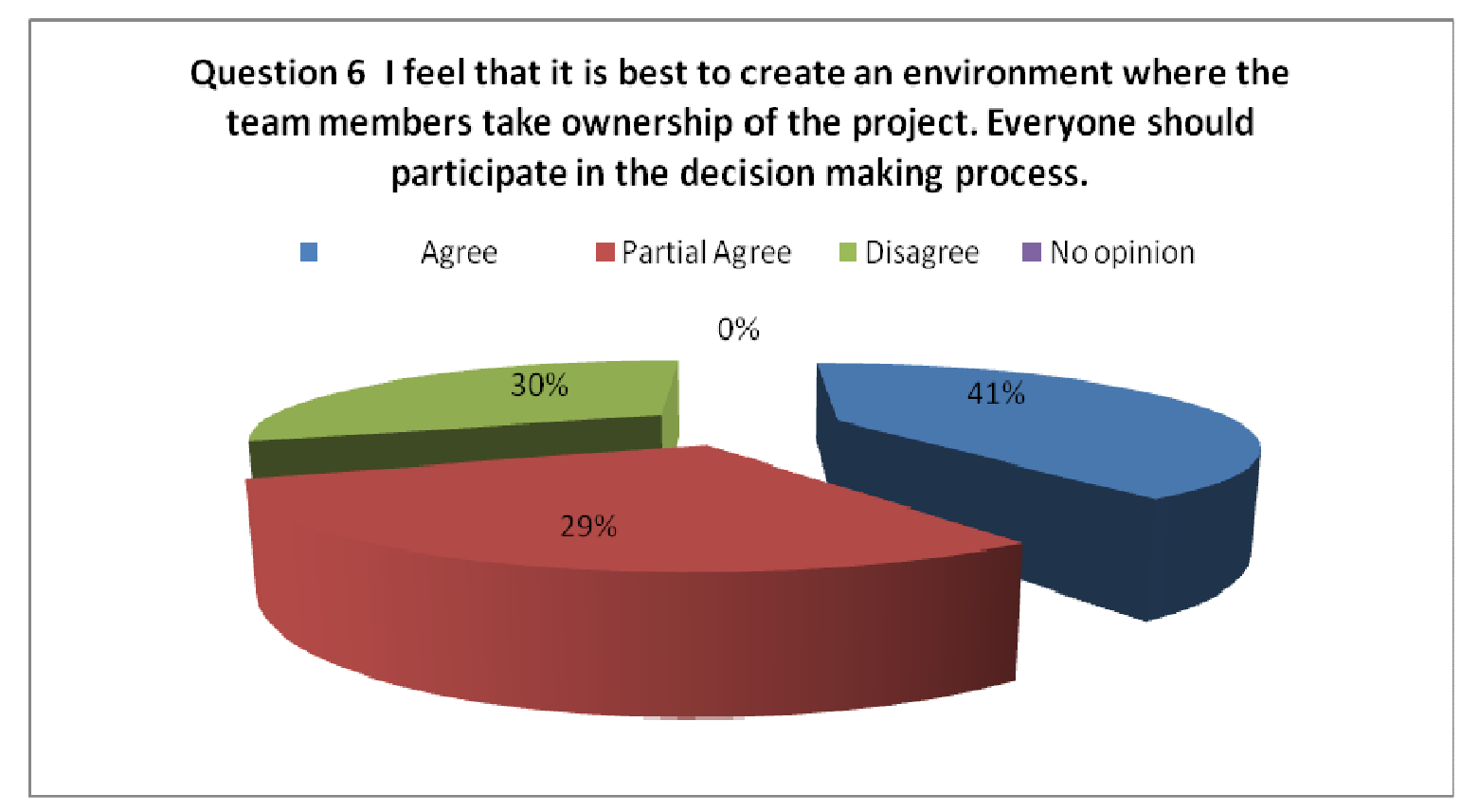

Figure 4.6: Necessity of Followers' Participation in Decision-Making Process

In Question 6, of the 69 interviewees, 28 (29\%) agree that everyone in the project should participate in the decision-making process. On a team project, it is necessary and important for everyone to participate in the process. However, a large number, $41 \%$, of respondents disagree with this question; identifying the reason for this level of disagreement is relevant to this research. Therefore, some telephone interviews are conducted to clarify this phenomenon. Respondents stated they considered time as an important factor in determining whether decisions should be made as a team or by the project manager; if every decision is made by all the team members, time would be 
wasted. Since the longer the project lasts, the more money it will cost; thus, if efficiency is a key factor in each project, not everyone should be participate in the decision-making process. However, this does not mean leaders should make all decisions alone. Instead, respondents suggested that representatives from the team should be selected to assist in the decision-making process. Respondents also suggested that, for some key decisions which can affect the whole project, everyone should participate and be responsible for making decisions.

Besides all the analysis above, the researcher also found an interesting phenomenon. As all questionnaires were sent both to people in the United States and China, the responses were almost the same. Making a second comparison based on different countries, the percentage rates are nearly the same. From this we can see that the cognitions from experts now are becoming more similar and the trend of the globalization will continue.

\subsubsection{Vision}

Question 7 focuses on the project vision. Respondents are asked to provide their level of agreement with the following statement:

Question 7: I feel that project manager should ask employees for their vision of where they see their jobs going and then use their vision where appropriate.

Respondents are asked whether they agree, partially agree, disagree or have no opinion on the above statement. Results are shown in Figures 4.7. 


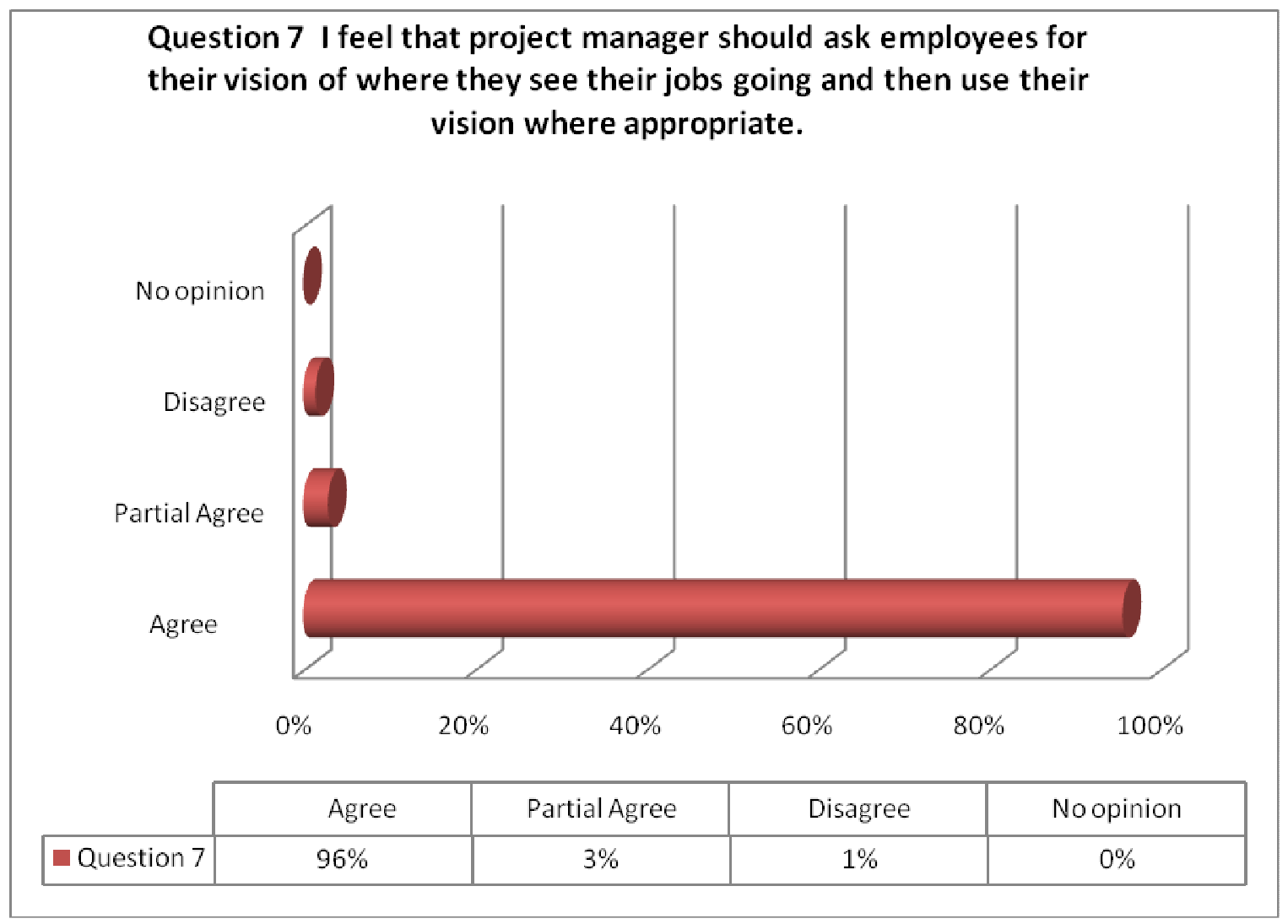

Figure 4.7: Importance of Followers' Vision

In Question 7, 66 (96\%) respondents believe project managers should take employees' opinions where appropriate. Since completing a project is a team effort, no one individual can claim success in a project without the contributions of others. In China, there is a saying: "A leader gains success and become great because of his or her followers". The survey results support the idea that leaders should gain opinions from the team members and consider team members an essential part to successful project execution.

According to research, among all successful leaders, their followers have some common characteristics, including: Respect for authority; Loyalty; Team Cooperation; Open-mindedness; Consideration; Keeping promises; Trusting others; Taking 
responsibility; Caring for others; and Good at listening. Projects succeed or fail not only because of how well leaders lead, but also because of how well followers follow. The most-effective team members are both capable of independent thinking and are actively committed to project goals; they also master skills that are useful to their teams, and they hold high performance standards.

\subsubsection{Leadership Skills}

Respondents are asked in Question 8 to identify, from a list a choices, the essential skills leaders should have.

Question 8: Please choose five most important skills you think a leader should obtain below.

- Understanding the needs and characteristics of the post

- Communication

- Knowing and using the resources of the group

- Planning

- Controlling group performance

- Setting the example

- Sharing leadership

- Counseling

- Evaluating

- Effective teaching

- Representing the group 


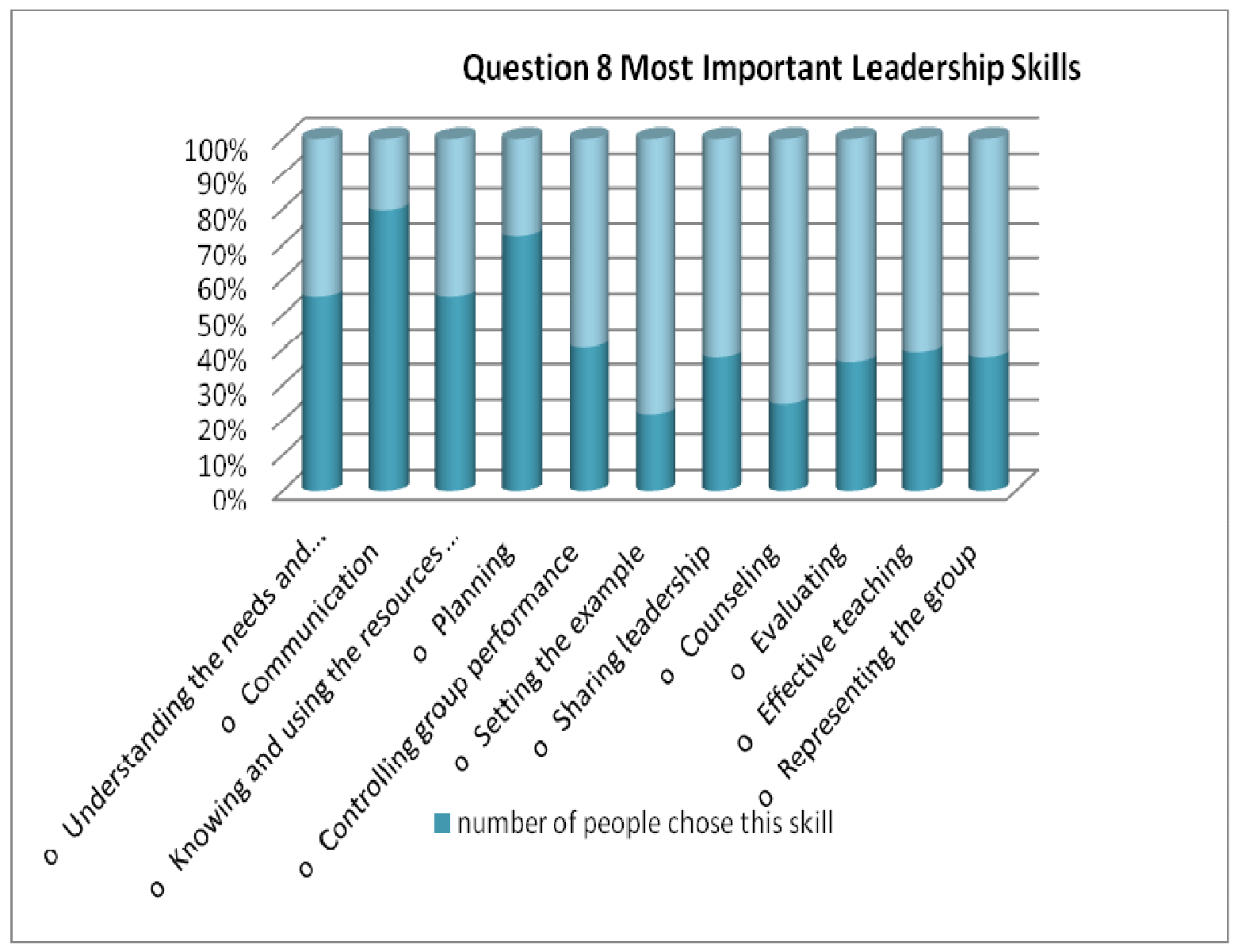

Figure 4.8: Top Leadership Skills

Each skill is considered important by survey respondents, as shown in Figure 4.8. The five most significant skills are determined and listed in Table 4.1 below. 
Table 4.1: Rank of Important Leadership Skills

\begin{tabular}{|c|c|c|}
\hline Leadership Skills & Quantity Chosen by People (69) & Rank \\
\hline Communication & 55 & 1 \\
\hline Planning & 50 & 2 \\
\hline $\begin{array}{c}\text { Knowing and using the } \\
\text { resources of the group } \\
\text { characteristics of the post }\end{array}$ & 38 & 3 \\
\hline $\begin{array}{c}\text { Controlling group performance } \\
\text { Enderstanding the needs and }\end{array}$ & 38 & 3 \\
\hline Representing the group & 28 & 5 \\
\hline Sharing leadership & 26 & 7 \\
\hline Evaluating & 26 & 10 \\
\hline Counseling & 25 & 11 \\
\hline Setting the example & 17 & 9 \\
\hline
\end{tabular}

The five most important leadership skills leaders should have, according to survey respondents, include: communication; planning; knowing and using the resources of the group; understanding the needs and characteristics of the post; and controlling group performance.

\subsubsection{Characteristics of Good Leaders}

Question 9 is designed to solicit the opinions of respondents regarding the characteristics they believe are essential to good leaders:

Question 9: Please list all the essential characteristics you believe a good leader should have. 
Question 9 does not provide multiple choices; rather, respondents are asked to provide their personal opinions without being directed by the researcher. Some survey participants did not answer this question and some answers did not exactly match for the purpose of this survey. After reduction and selection, typical answers are described below. Characteristics include: Face challenges and changes positively; Innovative spirit; Effective; Consider how to do things better and differently after one project; Take risks to propose new ideas bravely; A life-long learner; Inspire others toward a hopeful vision of the future; Be fair to everyone in the team; Develop and nurture effective working relationships; Share expertise and knowledge to help others develop; Remain positive attitudes during times of uncertainty and change; Foster respect and appreciation of team members' differences; Listen and attempt to understand others; Clearly and respectfully express others' needs, concerns, and views; Respond in a timely way to the concerns of others; Share communication in a clear way, via e-mail, memos, letters, reports, and conversations; Show appreciation for a job well done; Contribute to a spirit of teamwork and cooperation; Help others develop ways to overcome barriers; Encourage team to regularly assess its effectiveness; Manage time and resources efficiently; Anticipate and plan for problems and roadblocks; Make appropriate decisions, even under pressure; Ensure a balance between concern for people and concern for work results; Manage workload and achieve results on time and within budget; Delegate responsibility and authority to maximize use of employees' skills; and See interconnecting relationships among a variety of work-related issues.

The above characteristics reflect the respondents' beliefs concerning the traits a good leader should possess. These characteristics can also be used as the basis of leadership training, meaning these skills identified by respondents as important can be used to develop and train good leaders. 


\subsubsection{Respondents' Background}

The next series of questions are designed to gauge a respondent's experience level, position, education, and gender.

Question 10: I have worked on projects for_years.

Question 11: Your role is_.

Question 12: What is your level of education?

Question 13: Your gender:

Responses are shown in Figures 4.9 to 4.12.

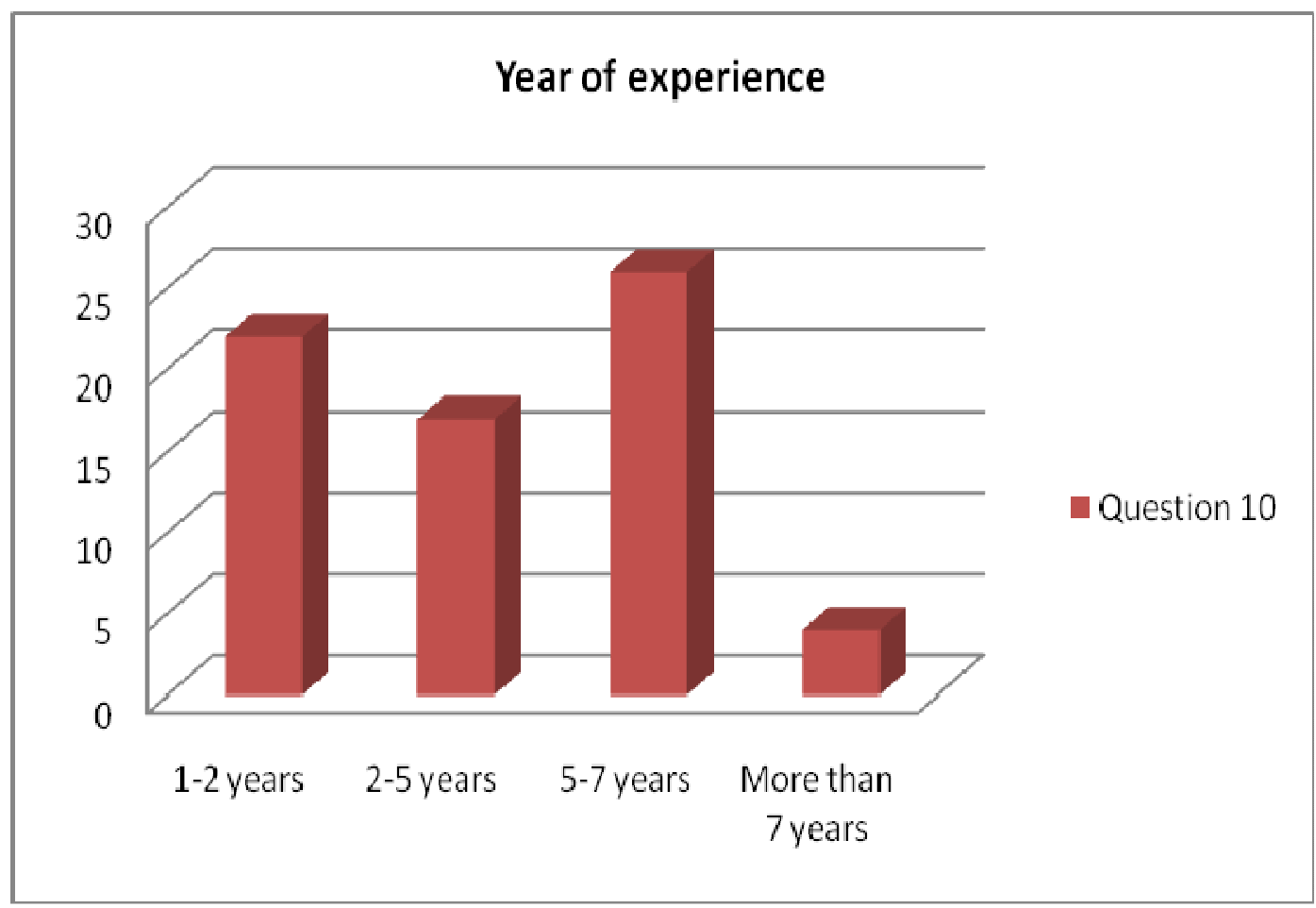

Figure 4.9: Years of Experience of Respondents 


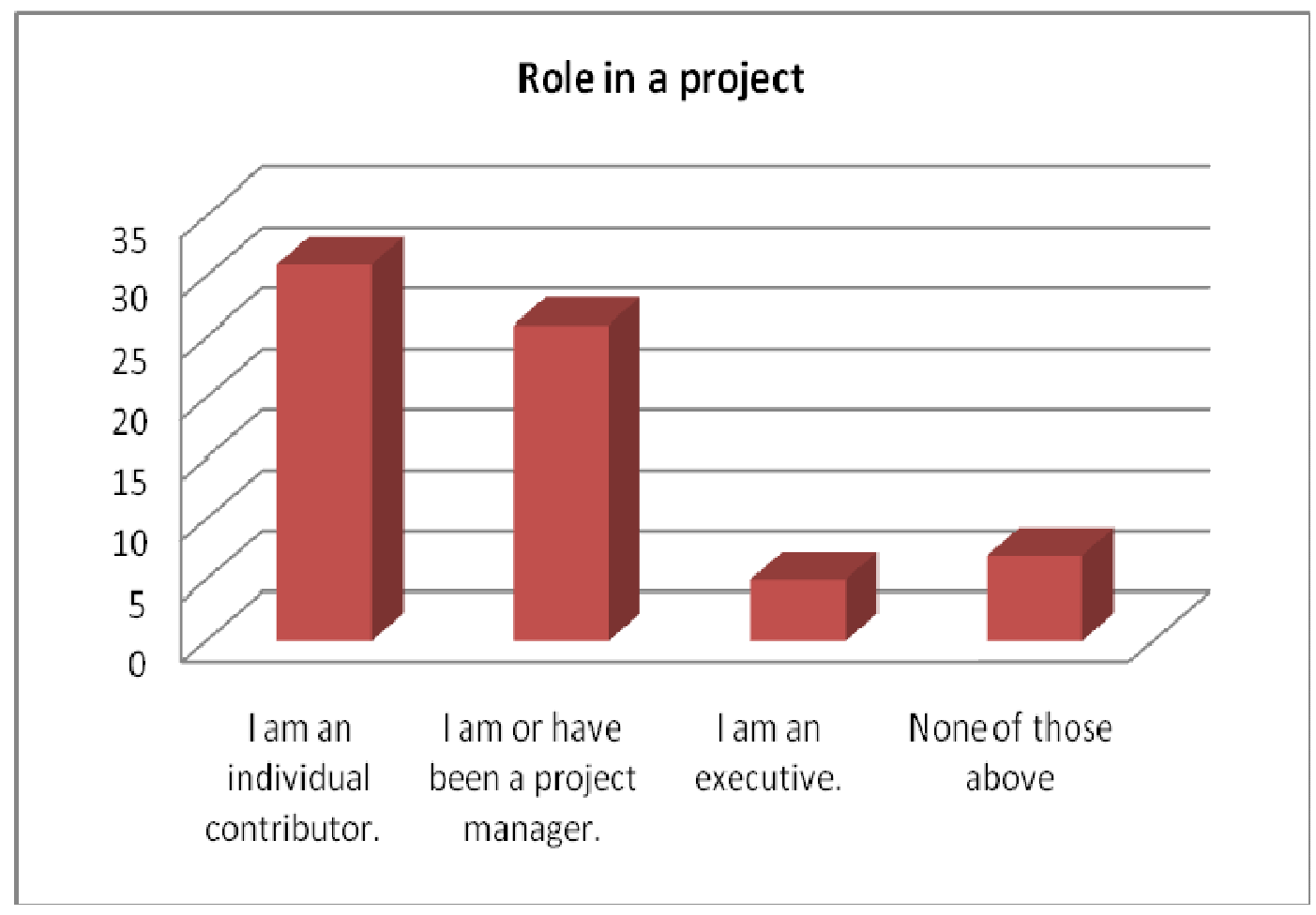

Figure 4.10: Respondents' Role in Projects

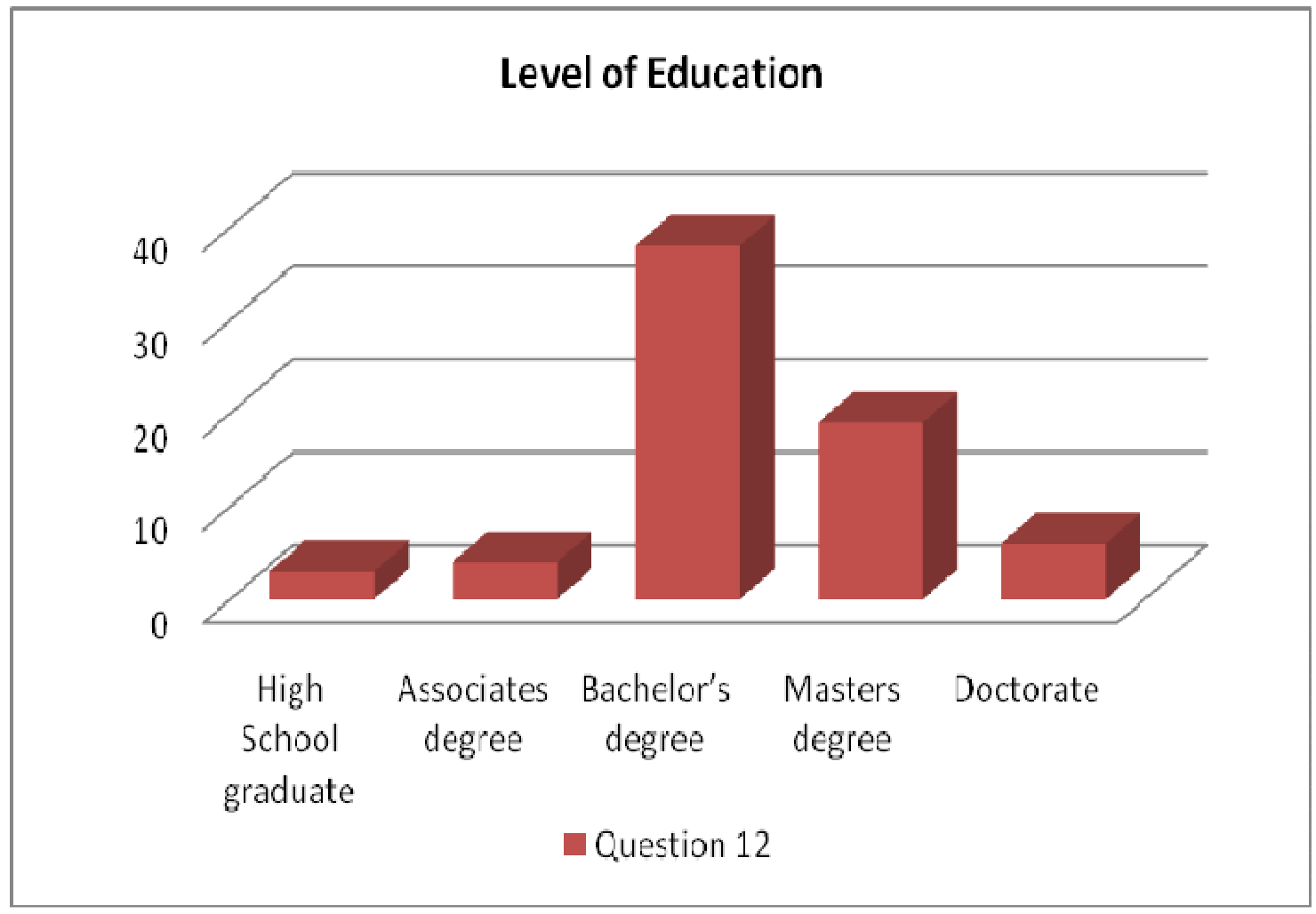

Figure 4.11: Respondents' Education Level 


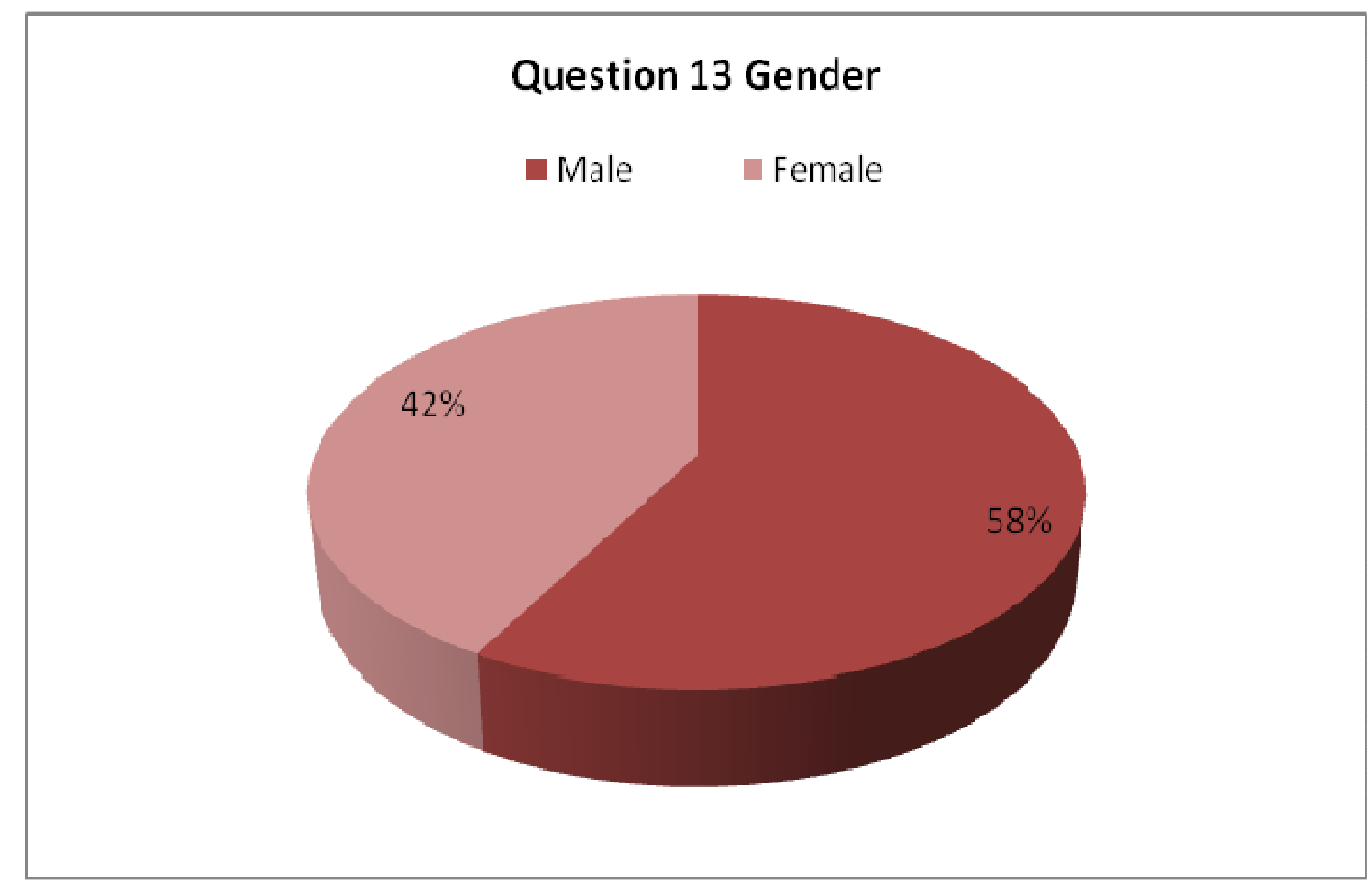

Figure 4.12: Resondents' Gender

Question 10,11, 12 and 13 are intended to collect general information from all the respondents.

\subsection{Results and Detailed Analysis}

In this stage, some additional interviews are conducted with several participants who are experts in the project management field, both in United States and China. Interviews are conducted using a set of open-ended questions concerning project leadership, in addition some questions used in the previous survey. The interviewees include project managers in large construction companies (Skanska, Turner, and Parsons), researchers, and university professors. The survey questions include:

1. "What are the basic characteristics and traits of a project leader?"

2. "What are the leadership skills that a project leader should have in order to make the project team effective and efficient?" 
3. "Do you think the top five important leadership skills are: communication, planning, knowing and using the resources of the group, understanding the needs and characteristics of the post and controlling group performances, which are the results from the previous survey?"

4. "Could you please give some suggestions to obtain leadership skills?"

Most interviewees agree concerning the basic characteristics and traits for a project leader. These characteristics include: forward-looking; competent; inspiring; intelligent; enterprising spirit; loyalty; leadership motivation; integrity; self-confidence; and knowledgeable of the business. As identified by this group of experts, one of the important traits is the ability to communicate effectively. According to the previous survey, communication skills are the most important characteristic of leaders; communication skills are named first of 11 skills listed in the questionnaire. As affirmed by the survey and interview participants, successful leaders are great communicators. Great communication involves writing, speaking and listening. Good leaders also have clear objectives. They are clear on what their own personal values are, what they stand for as a leader, what they want to create as a leader, and what they can be relied on for. Essentially, these leaders live by their values and use them as a reference point when it comes to making key decisions.

Inspiration is another typical trait for leaders. Leaders need to motivate and inspire others in order to successfully complete a project and to deliver on areas, such as strategy, project change, human resource development, financial management and business development. Inspiring others is more than just word; it is about demonstrating that you can be relied upon, trusted, and is genuinely interested in others and their success. 
An ancient Chinese Philosopher Lao Tzu suggested more than 15 centuries ago: "a leader is best when people barely know he exists." Meaning, that when that leader's work is done, those he led would say, "We made it ourselves." In other words, a good leader can influence his or her followers through subtle words, actions, and attitudes, which allows team members to take charge and complete the project.

Several suggestions are given by interviewees on how to gain leadership skills:

1. Observing methods and skills of leaders that you respected.

2. Taking risks, trying, and learning from mistakes.

3. Reading autobiographies of leaders you admire to try to understand how they think.

4. Practicing.

5. Making mistakes and overcoming them.

6. Purposely engaging with others to get things done.

7. Being responsible in the team project.

In addition, one respondent commented: "One should get out of his or her “comfort zone". Meaning, leaders should constantly seek and create challenging situations that require them to adapt and change. Often, this is the best and quickest way to learn. 


\section{CHAPTER 5}

\section{CASE STUDY}

\subsection{Introduction}

Over the past several years, the topic of leadership has emerged as a key topic in the field of project management. Although a number of researchers have conducted studies in this field, there is still a lack of research focusing specifically on construction companies.

\subsection{Skanska USA Building Case}

\subsubsection{Background}

Skanska is one of the world's leading construction groups (General Contractor). In the United States, it is a provider of comprehensive construction services and a developer of public-private partnerships. The Skanska group currently has 60,000 employees worldwide; more than 9,000 of whom work in the United States. At any one time, the company may have about 1,500 projects taking place in almost all of the 50 states. Headquartered in Whitestone, New York, the combined sales of Skanska USA's business units totaled more than $\$ 5.6$ billion in 2007 . Its services include preconstruction, construction management, start-up and commissioning, facility turnover, and designbuild. Its market segments include: Colleges \& Universities; Commercial/Corporate; Government; Healthcare; High Tech/Semiconductor; Industrial; Pharmaceutical/Biotech; Retail; Sports \& Entertainment; Telecom/Data Centers; and Transportation. 
Skanska is the first U.S. construction firm to have all of its operations uphold the ISO 14001 Environmental Management System (EMS) standard, which immediately earns it one LEED ${ }^{\circledR}$ credit on all its projects. ISO-14001 Certification is an international, voluntary management standard addressing EMS, and includes internal auditing, documentation, self-regulation, and integrated environmental management. Skanska's ISO-14001 Certification Certificate is shown in Figure 5.1.

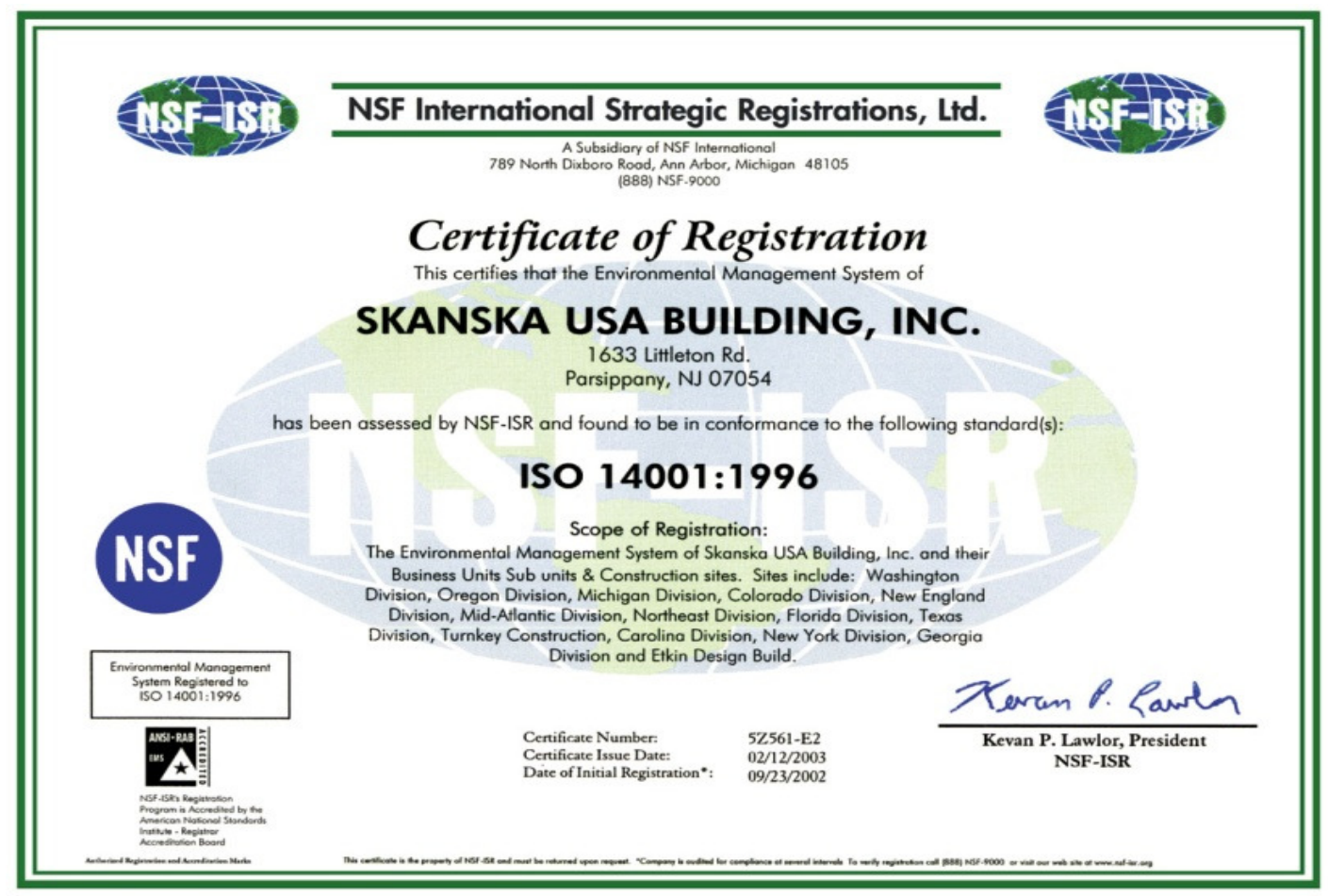

Figure 5.1: Skanska's ISO-14001 Certification

Skanska is also currently ranked as the number one green builder in the United States by Engineering News-Record (ENR). Some of its LEED projects include:

- EPA National Computer Center - RTP

- Hillsboro Civic Center - Hillsboro, OR

- Oregon State Univ. - Kelley Engineering Building 
- University of Florida - McGuire Center

- Seattle University - Student Center

- McCaw Performance Hall - Seattle, WA

- US Census Bureau - Washington, DC

- MIT - Ray \& Maria Stata Center

- Duke University - CIEMAS

\subsubsection{Leadership Theory}

All new employees hired by Skanska, whether interns or project managers, are required to learn the 10 Commandments of the company. The 10 Commandments are a collection of Skanska's core best practices which are fundamental in successful construction management; they are considered the top requirements for the company and for each project.

One of the commandments is called "The BIG BOSS." It compares the concept of 'boss' with that of 'leader' in several ways:

The boss drives people; the leader coaches them. The boss depends on authority; the leader on good will. The boss inspires fear; the leader inspires enthusiasm. The boss says 'I'; the leader says 'we'. The boss says 'Get here on time'; the leader gets there ahead of time. The boss fixes blames for the breakdown; the leader fixes the breakdown. The boss knows how it is done; the leader shows how. The boss says 'GO'; the leader says 'LET'S GO'. The boss uses people; the leader develops them. The boss sees today; the leader also looks at tomorrow. The boss commands; the leader asks. The boss never has enough time; the leader makes time for things that count. The boss is concerned with things; the leader is concerned with people. The boss works hard to produce; the leader works hard to help people produce. The boss takes the credit; the leader gives it (Skanska, 2008). 


\subsubsection{Leadership Training in Skanska}

In summer 2008, the researcher had the opportunity to work in the preconstruction department with Skanska in the Atlanta, Georgia office. After getting involved in several projects, it became evident that team collaboration and leadership skills are of significant importance to the whole department. Projects are divided using WBS (Work Breakdown System) into several packages and assigned to each individual in the same team by the project manager. The Skanska philosophy is that, in order to be successful, employees should always be enthusiastic, be prepared, be humble, and proactive; then, one becomes a leader. The following two figures demonstrate the company's leadership expectation for new employees, which includes four steps for life-

long development. As shown in Figure 5.2, the company emphasizes leadership development at all levels of employment. Effective leadership development facilitates personal growth and enhances career growth. 


\section{Skanska Leadership Development}

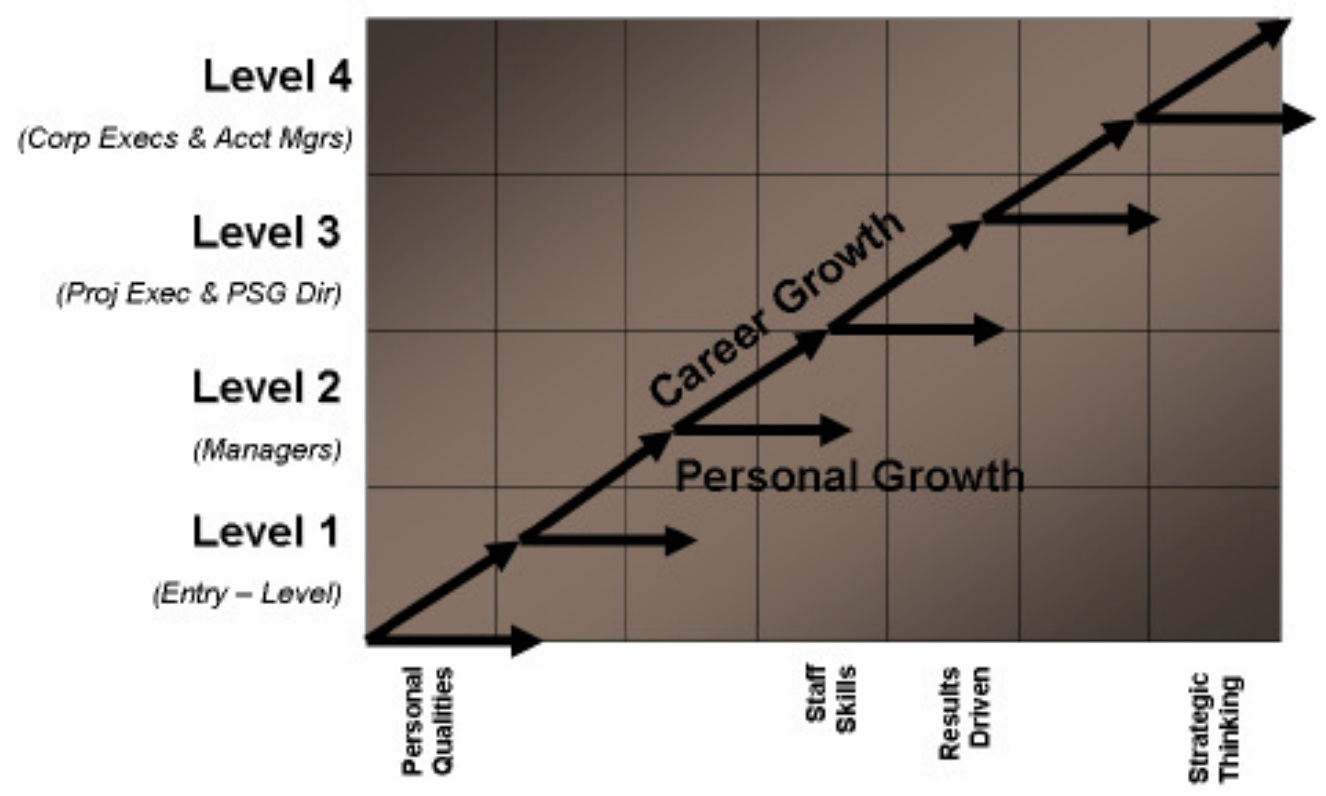

Figure 5.2: Skanska Leadership Development

Through its management development plan, shown in Figure 5.3, employees participate in 'Skanska University' to hone their leadership skills. Based on the previous survey Question 2, more than half of the respondents believe that training is important and necessary. Skanska's own training programs can support this and make it more convincing. The program at Skanska emphasizes that, by studying, coaching, participating in leadership development programs, and talent reviews, one can become a successful leader in his or her career life. 


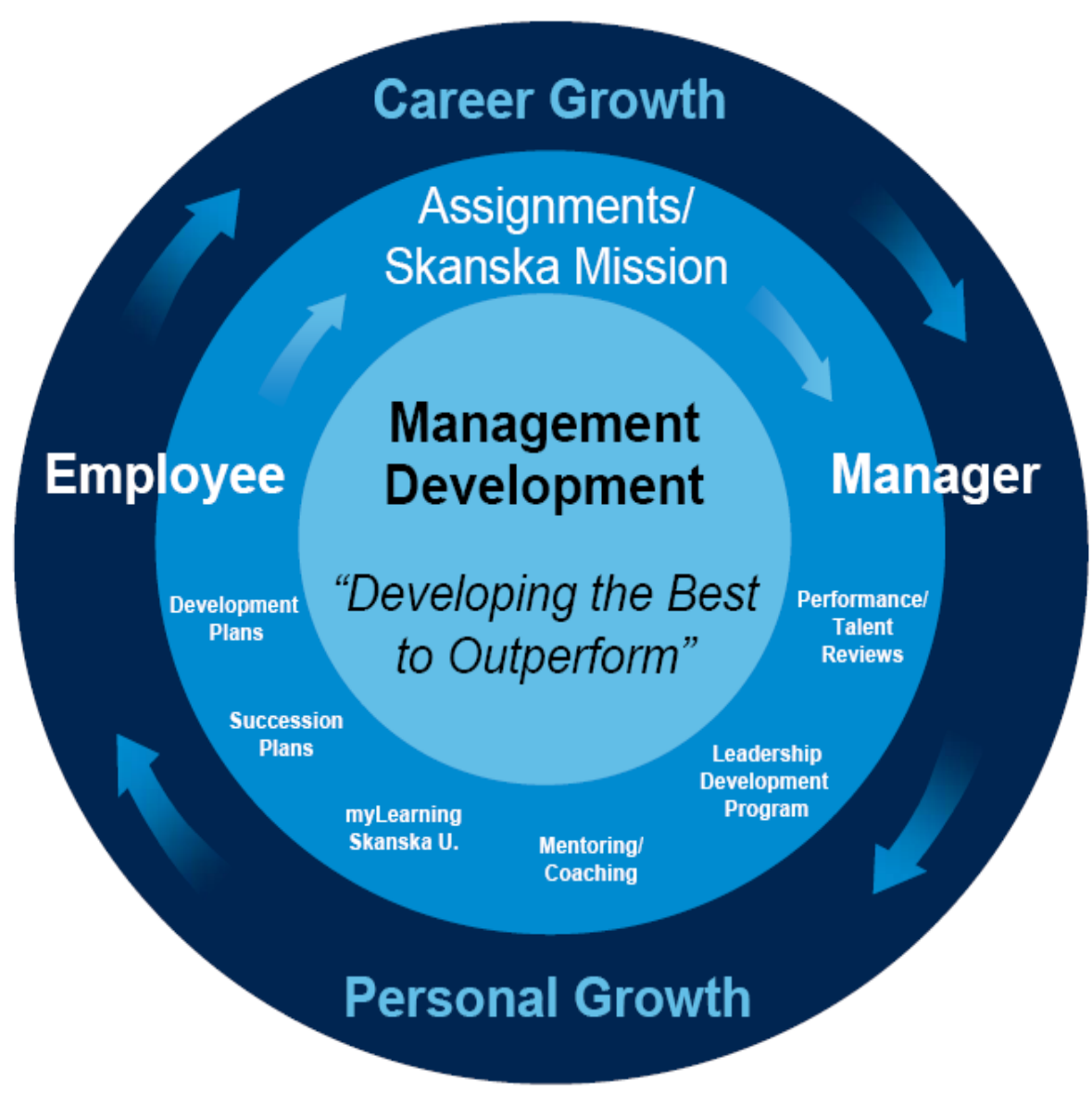

Figure 5.3: Skanska's Management Development

\subsubsection{Case Conclusion}

Skanska put incredible emphasis on leadership development because they recognize the significance and value of leadership within their organization. This is also the trend as we see in the previous survey. In satisfying the demands of economic development and the demands of globalization, in which more projects, are completed with people all over the world, Skanska recognizes the role of quality management. However, effective and efficient management cannot happen without good leadership skills in construction projects, as well as other industries. Skanska's unique approach to leadership development helps maintain the company's overall success. It also provides a 
model in which others can emulate. From the Skanska case, it is clear that leadership needs to be developed and that individuals need formal training in leadership skills.

The previous survey is a perception-based results from all the questions provided to the interviewees. It has some limitations to support the entire research. The case study, plus the basic journal and data base review, therefore, makes the research analysis and process convincing and accurate. 


\title{
CHAPTER 6
}

\section{CONCLUSIONS AND RECOMMENDATIONS}

\begin{abstract}
6.1 Summary
Leadership is one of the most important and essential factors in good project management. Leadership is more than simply managing people or projects: it is the art of affecting other team members' behavior in order to achieve the goals and accomplish the tasks successfully.

The survey results confirm that an individual who demonstrates leadership skills will be promoted more easily. Thus, employees need this trait in order to achieve their career goals. However, quality leadership is important not only for individual's career pursuits, but is also significant because it influences the whole project process. Moreover, leadership is growing in importance, particularly in light of the booming contruction market and the shift toward global projects and global project teams. Because the world is changing, and because problems and projects are becoming even more complex, one can no longer assume that a sole executive or manager can solve all problems by himself or herself. No one person can deal with all of today's rapid changes, competitive threats, and escalating customer demands. Instead, effective leadership must permeate the organization.
\end{abstract}

As demonstrated by the literature review, good leaders are made not born. Those with the desire and ambition can elevate to a position of leadership and develop the tools to become an effective leader through a continuing process of self-study, education, 
training, and experience. Those who wish to gain leadership skills should observe the methods and skills of those leaders they respect, or read the autobiographies from those great leaders they admire.

Although the perception- based survey has some limitations to support the entire research, other literature review including journals, books and the case study make the entire research convincing. From both the case study and the survey data, it demonstrates that the first step in gaining leadership skills is to develop a clear vision of self. Good leaders can make fair judgments toward themselves, and acknowledge both their strengths and weaknesses. They have goals and a vision, and effectively communicate their vision through words, mannerism, or actions. Successful leaders have a desire to take responsibility, to innovate, and to initiate. They are not content with merely taking care of what is already there; rather, they want to move forward to create something new. Leaders provide answers, as well as direction, offer strength, dedication, and speak from experience, as well as understanding the problem at-hand and understanding the needs of the people they work with. Successful leaders can build trust by being consistent, dependable, and persistent. While good leaders have a positive view of themselves, they do not feel self-important; rather, they recognize their personal strengths, compensate for their weaknesses, nurture and continually develop their talents, and know how to learn from failure. They also strive for success, rather than merely trying to avoid failure. Building leadership skills requires taking risks and learning from those mistakes. Staying in easy, non-challenging situations will never make a good leader; rather, facing difficult situations that require you to adapt and make changes is the best way to obtain leadership skills. Besides all of the actions mentioned above, as demonstrated by the results of the 
survey and the case study, in order to gain leadership skills, formal training is also necessary, and a must for the one who wants to gain success in the future. 


\section{APPENDIX A}

\section{SURVEY: LEADERSHIP AND THE PROJECT}

\section{MANAGEMENT IN CONSTRUCTION FIELD}

Hello,

You are invited to take part in a research study about leadership in project management. The study deals with the relationship between leadership and project management practices. The study is being conducted by Riyue Xiong, in Building Construction program, Georgia Institute of Technology as part of a thesis project for the Masters of Science degree. The advisor for this study is Kathy O. Roper, CFM, CFMJ, MCR, LEED AP, IFMA Fellow, and Associate Professor of Building Construction program at Georgia Institute of Technology.

If you agree to participate in the study, you will be asked to complete in the following survey consisting of general statements/questions, and demographic questions that will take no more than 10 minutes.

Risk assessment: there is no risk to participation in this study beyond that of everyday life. All of your responses are anonymous and confidential. No individual participant will be identified. No attempt will be made to ascertain your identity. The only information mentioned in any reporting, publication or presentation will be in summary form. While I would prefer that all participants answered all questions, if at any time you do not wish to answer a question, you are free to not answer. Your participation in the study is voluntary; you may choose not to participate or withdraw from participation at any time without penalty. If you have any questions, please contact me at: rxiong3@ gatech.edu Thank you for your help in completing this project.

Riyue Xiong

Building Construction program

College of Architecture

Georgia Institute of Technology

Email: rxiong3@gatech.edu 
1. Leadership is necessary in completing projects successfully. Agree_ Partial Agree_ Disagree_ No opinion_

2. It is important for a leader to have formal leadership training to be successful. Agree_ Partial Agree_ Disagree_ No opinion_

3. I feel that successful project managers have high level leadership skills. Agree_Partial Agree_ Disagree_ No opinion_

4. I feel extremely satisfied with my job when working for a project manager. Agree_Partial Agree_ Disagree_ No opinion_

5. I feel that it is important for someone to demonstrate leadership in order to be promoted to a leadership position.

Agree_ Partial Agree_ Disagree_ No opinion_

6. I feel that it is best to create an environment where the team members take ownership of the project. Everyone should participate in the decision making process.

Agree_ Partial Agree_ Disagree_ No opinion_

7. I feel that project manager should ask employees for their vision of where they see their jobs going and then use their vision where appropriate.

Agree_ Partial Agree_ Disagree_ No opinion_

8. Please choose five most important skills you think a leader should obtain below.

- Understanding the needs and characteristics of the post

- Communicating

○ Knowing and using the resources of the group

$\circ$ Planning

- Controlling group performance

- Setting the example

- Sharing leadership

○ Counseling

$\circ$ Evaluating

$\circ$ Effective teaching

- Representing the group

9. Please list all the essential characteristics you believe a good leader may have. 
10. I have worked on projects for

○ Less than 6 months

○ 1-2 years

○ 2-5 years

○ 5-7 years

- More than 7 years

11. Your role is:

- I am an individual contributor.

- I am or have been a project manager.

- I am an executive.

12. What is your level of education?

- High School graduate

- Associates degree

- Bachelor's degree

- Masters degree

- Doctorate

13. Your gender:

- Male

- Female 


\section{APPENDIX B}

\section{SURVEY DATA COLLECTION}

Total Response Number: 69

Excel Analysis

Question 1 Leadership is necessary in completing projects successfully.

\begin{tabular}{|c|c|c|l|}
\hline Agree & Partial Agree & Disagree & No opinion \\
\hline 62 & 6 & 1 & 0 \\
\hline
\end{tabular}

Question 1: Leadership is necessary in completing projects successfully.

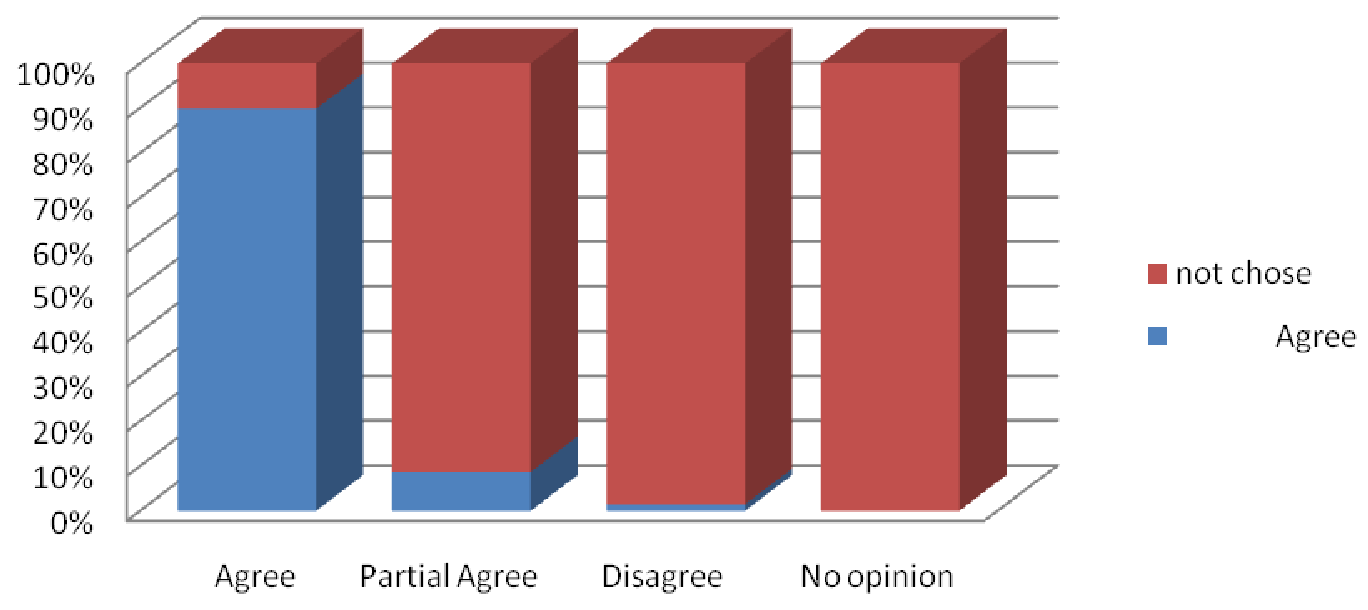


Question 2 It is important for a leader to have formal leadership training to be successful.

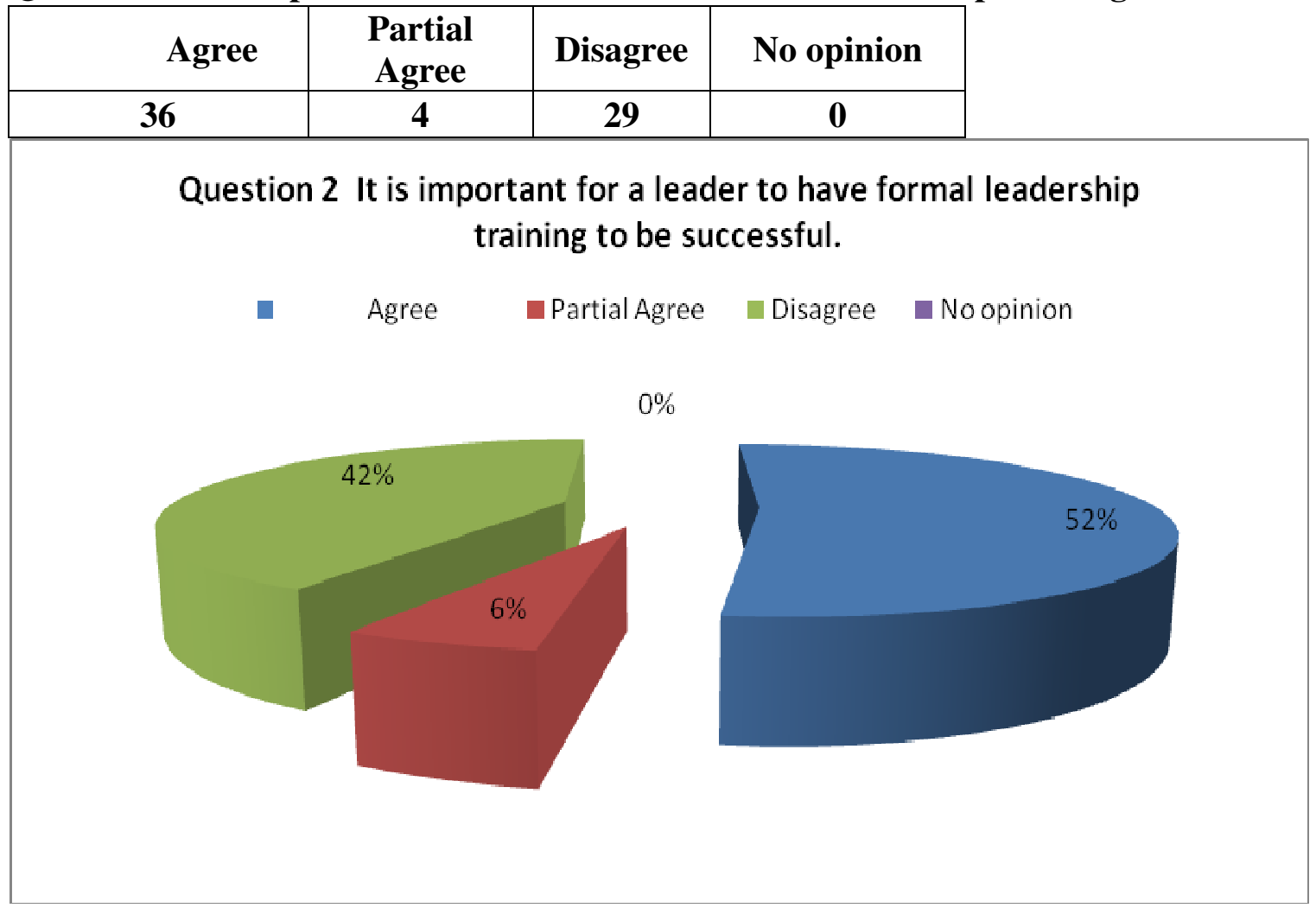


Question 3 I feel that successful project managers have high level leadership skills.

\begin{tabular}{|c|c|c|c|}
\hline Agree & $\begin{array}{c}\text { Partial } \\
\text { Agree }\end{array}$ & Disagree & No opinion \\
\hline 50 & 6 & 12 & 1 \\
\hline
\end{tabular}

Question 3 I feel that successful project managers have high level leadership skills.

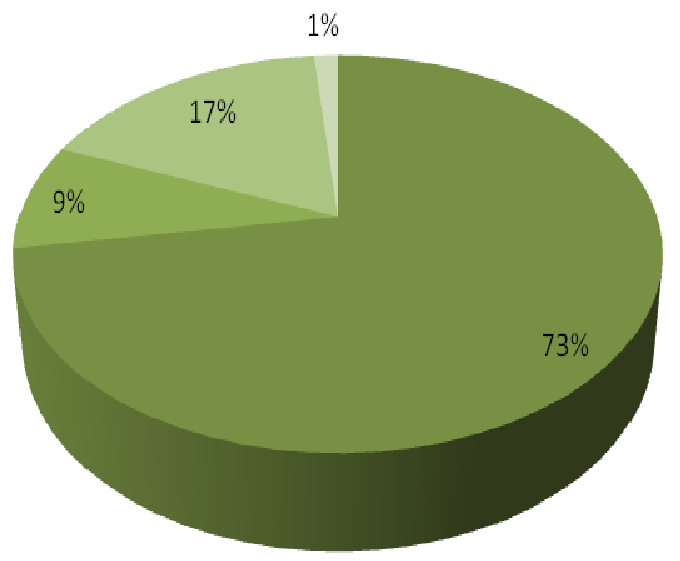


Question 4. I feel extremely satisfied with my job when working for a project manager.

\begin{tabular}{|c|c|c|c|}
\hline Agree & $\begin{array}{c}\text { Partial } \\
\text { Agree }\end{array}$ & Disagree & No opinion \\
\hline 15 & 28 & 21 & 5 \\
\hline
\end{tabular}

Question 4. I feel extremely satisfied with my job when working for a project manager.

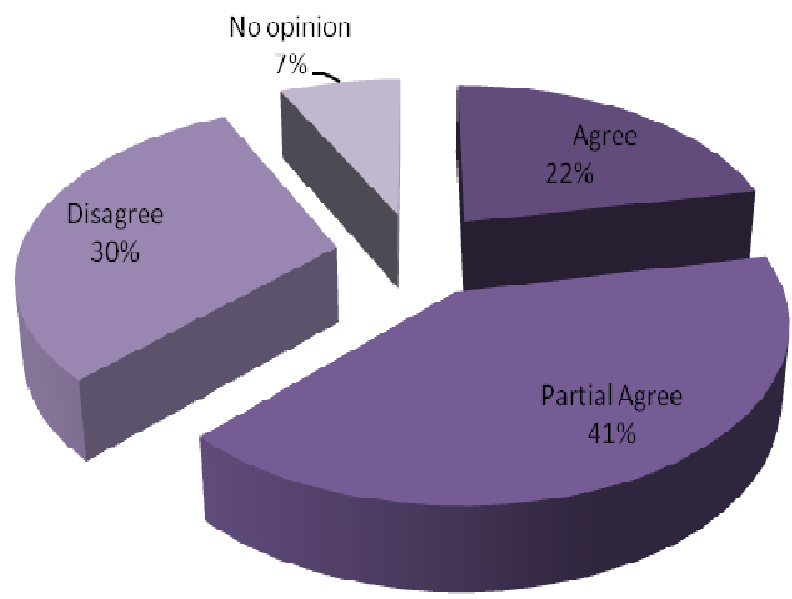


Question 5 I feel that it is important for someone to demonstrate leadership in order to be promoted to a leadership position.

\begin{tabular}{|c|c|c|c|}
\hline Agree & $\begin{array}{c}\text { Partial } \\
\text { Agree }\end{array}$ & Disagree & No opinion \\
\hline 65 & 2 & 2 & 0 \\
\hline
\end{tabular}

Question 5 I feel that it is important for someone to demonstrate leadership in order to be promoted to a leadership position.

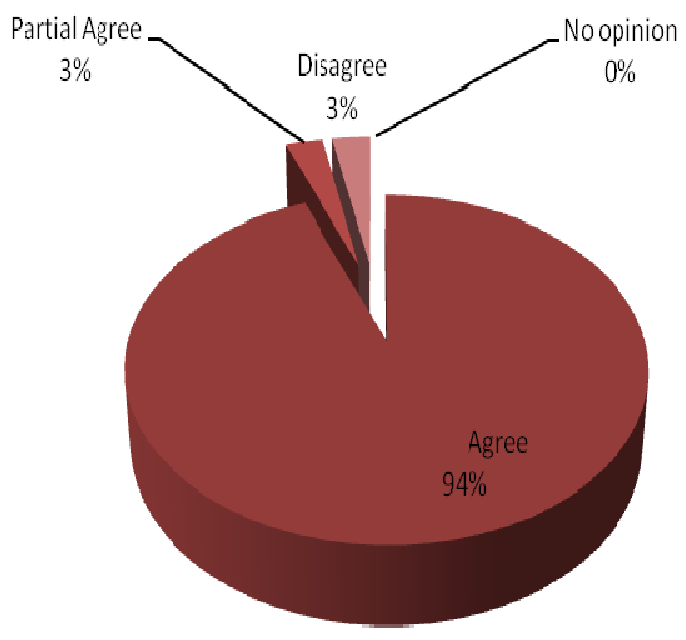


Question 6 I feel that it is best to create an environment where the team members take ownership the decision making process.

\begin{tabular}{|c|c|c|c|}
\hline Agree & $\begin{array}{c}\text { Partial } \\
\text { Agree }\end{array}$ & Disagree & No opinion \\
\hline 28 & 20 & 21 & 0 \\
\hline
\end{tabular}

Question 6 I feel that it is best to create an environment where the team members take ownership of the project. Everyone should participate in the decision making process.

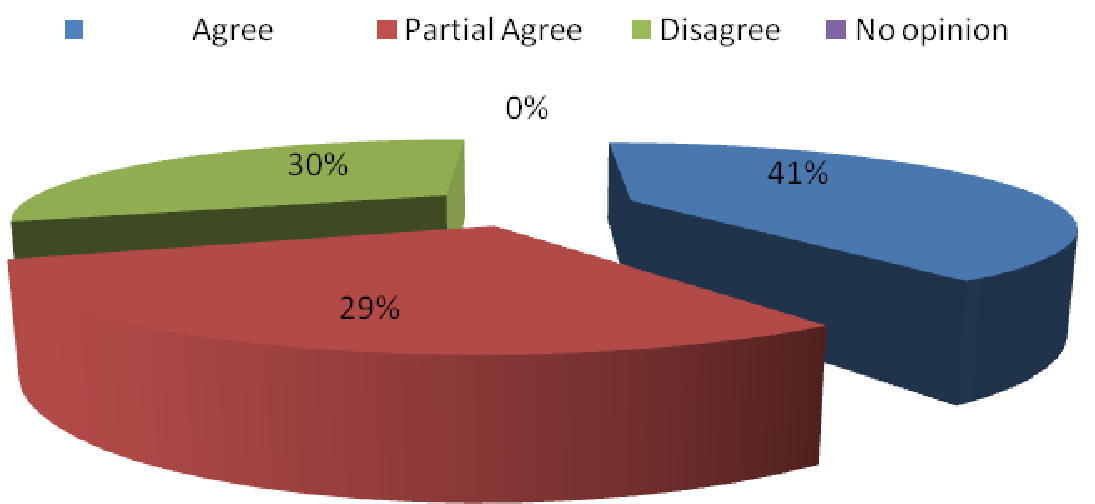


Question 7 I feel that project manager should ask employees for their vision of where they see their jobs going and then use their vision where appropriate.

\begin{tabular}{|c|c|c|c|}
\hline Agree & $\begin{array}{c}\text { Partial } \\
\text { Agree }\end{array}$ & Disagree & No opinion \\
\hline 66 & 2 & 1 & 0 \\
\hline
\end{tabular}

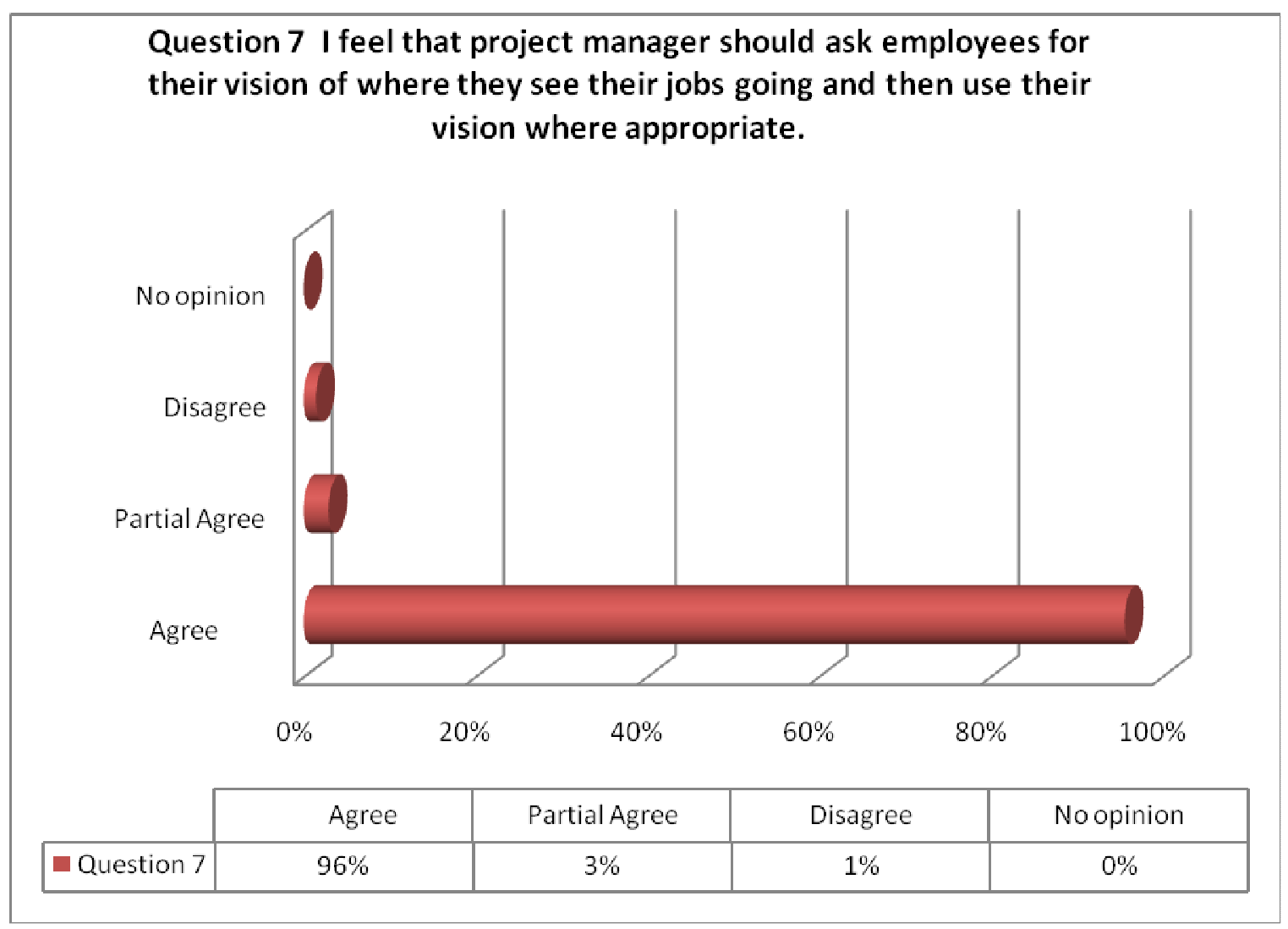


Question 8 Please choose five most important skills you think a leader should obtain below.

\begin{tabular}{|c|c|c|c|c|}
\hline Skills & Total & Selected & Unselected & Rank \\
\hline $\begin{array}{c}\text { o Understanding the needs and } \\
\text { characteristics of the post }\end{array}$ & 69 & 38 & 31 & 3 \\
\hline $\begin{array}{c}\text { o Communication } \\
\text { o Knowing and using the }\end{array}$ & 69 & 55 & 14 & 1 \\
\hline $\begin{array}{c}\text { resources of the group } \\
\text { o Planning }\end{array}$ & 69 & 50 & 19 & 2 \\
\hline $\begin{array}{c}\text { o Controlling group } \\
\text { performance }\end{array}$ & 69 & 28 & 41 & 5 \\
\hline o Setting the example & 69 & 15 & 54 & 11 \\
\hline o Sharing leadership & 69 & 17 & 52 & 10 \\
\hline o Counseling & 69 & 25 & 44 & 9 \\
\hline o Evaluating & 69 & 27 & 42 & 6 \\
\hline o Effective teaching & 69 & 26 & 43 & 7 \\
\hline
\end{tabular}

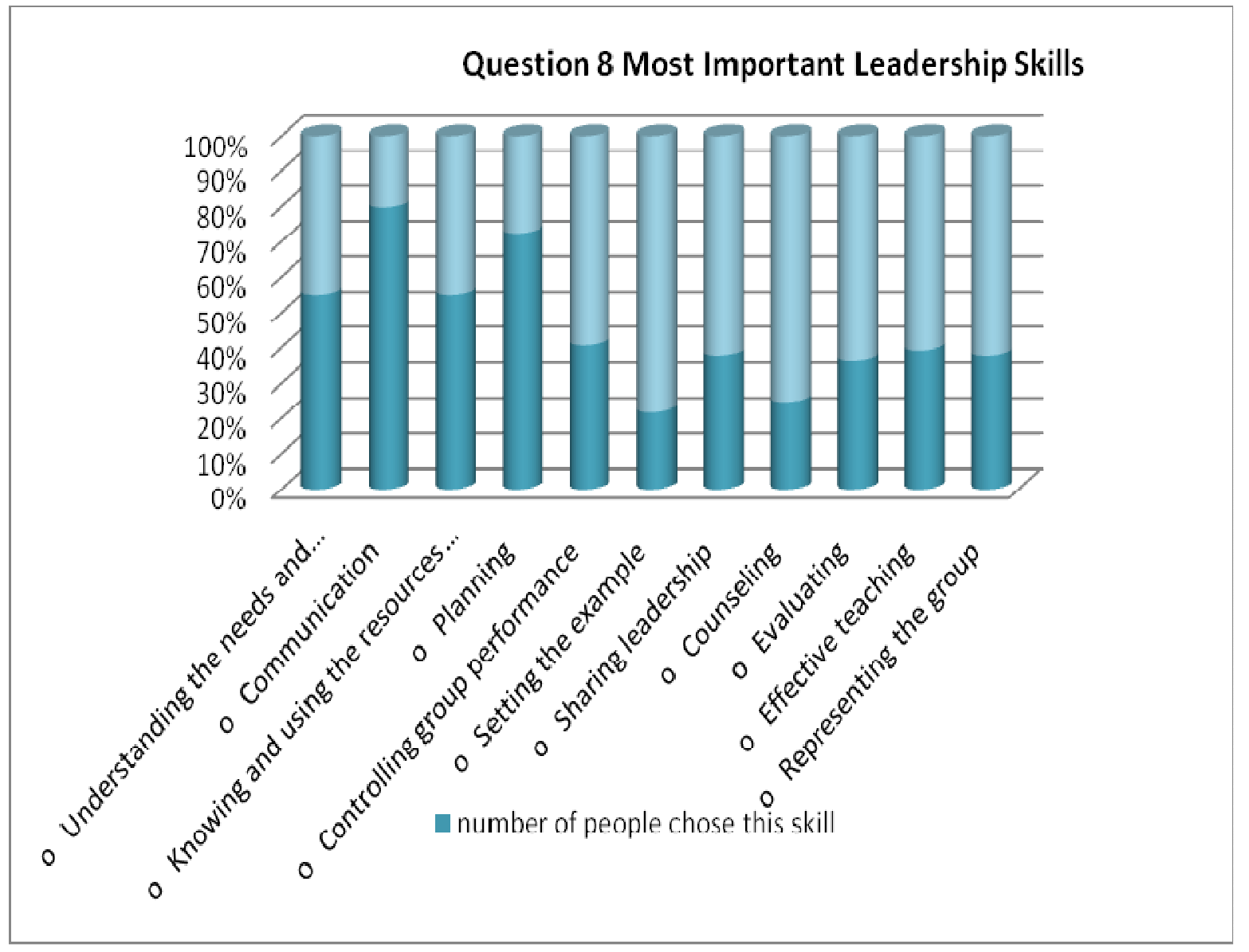


Question 9 Please list all the essential characteristics you believe a good leader may have. Question 10 I have worked on projects for

\begin{tabular}{|l|r|}
\hline $1-2$ years & 22 \\
\hline 2-5 years & 17 \\
\hline 5-7 years & 26 \\
\hline $\begin{array}{l}\text { More than } 7 \\
\text { years }\end{array}$ & 4 \\
\hline
\end{tabular}

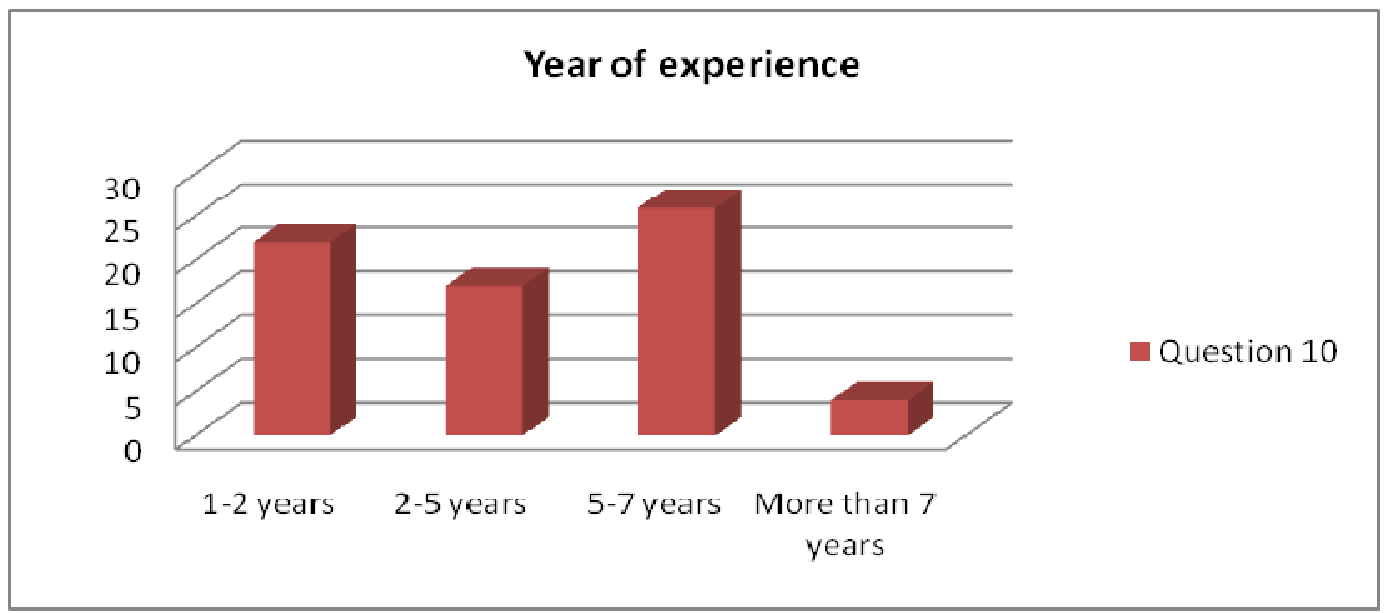

Question 11 Your role is:

\begin{tabular}{|c|c|}
\hline I am an individual contributor. & 31 \\
\hline $\begin{array}{c}\text { I am or have been a project } \\
\text { manager. }\end{array}$ & 26 \\
\hline I am an executive. & 5 \\
\hline None of those above & 7 \\
\hline
\end{tabular}

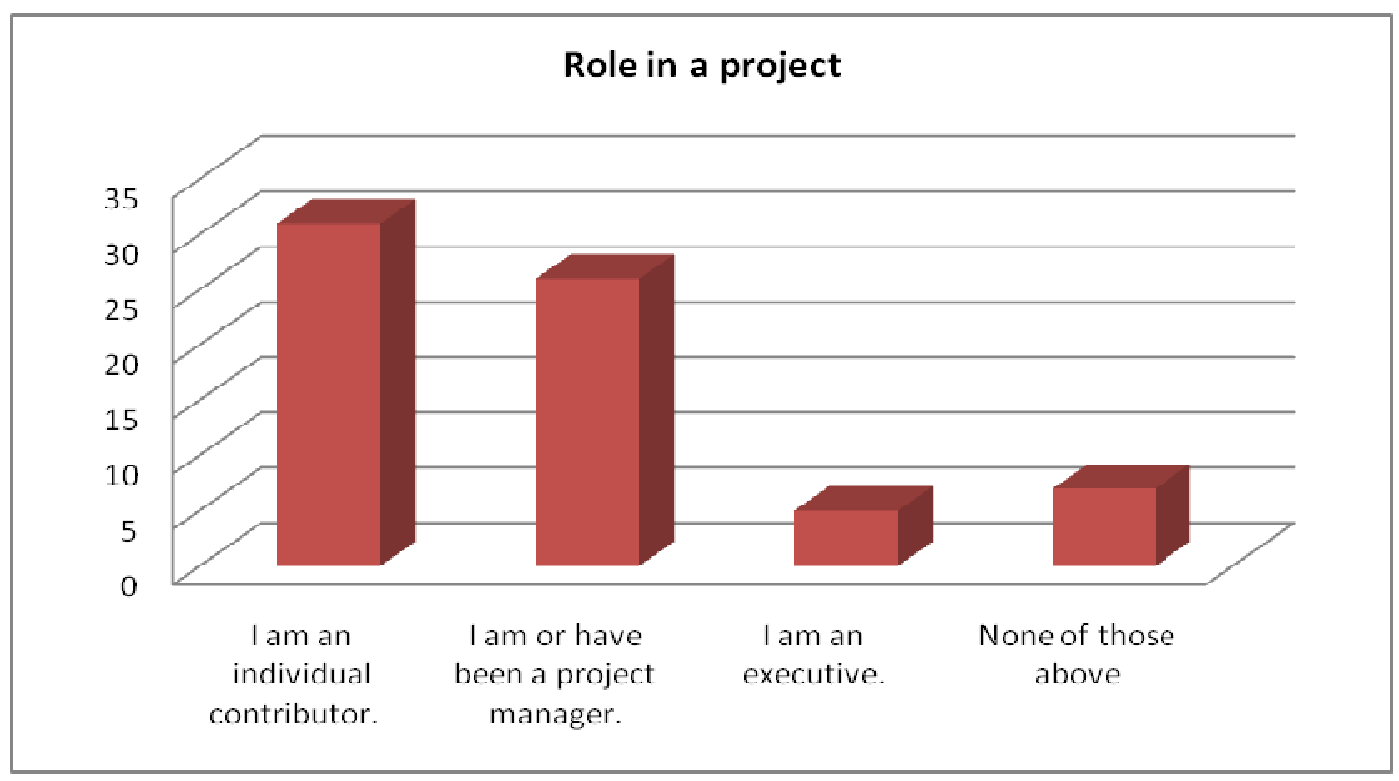


Question 12 What is your level of education?

\begin{tabular}{|c|c|}
\hline High School graduate & 3 \\
\hline Associates degree & 4 \\
\hline Bachelor's degree & 38 \\
\hline Masters degree & 19 \\
\hline Doctorate & 6 \\
\hline
\end{tabular}

\section{Level of Education}

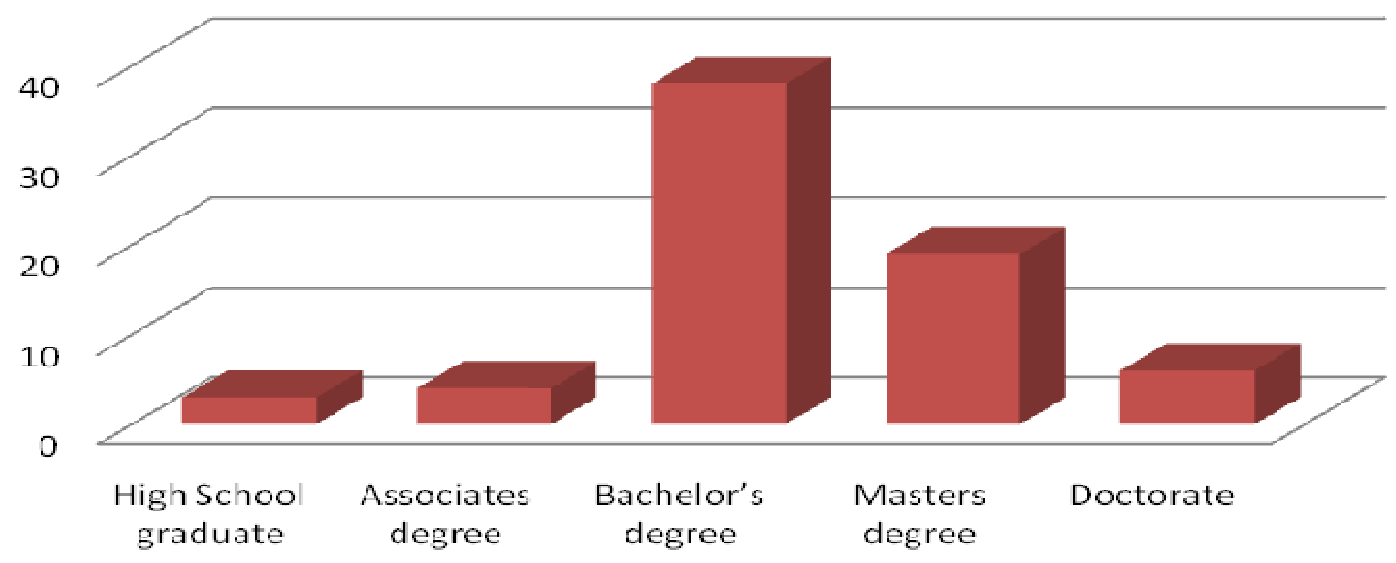

- Question 12 
Question 13 Your gender:

\begin{tabular}{|l|r|}
\hline Male & 40 \\
\hline Female & 29 \\
\hline
\end{tabular}

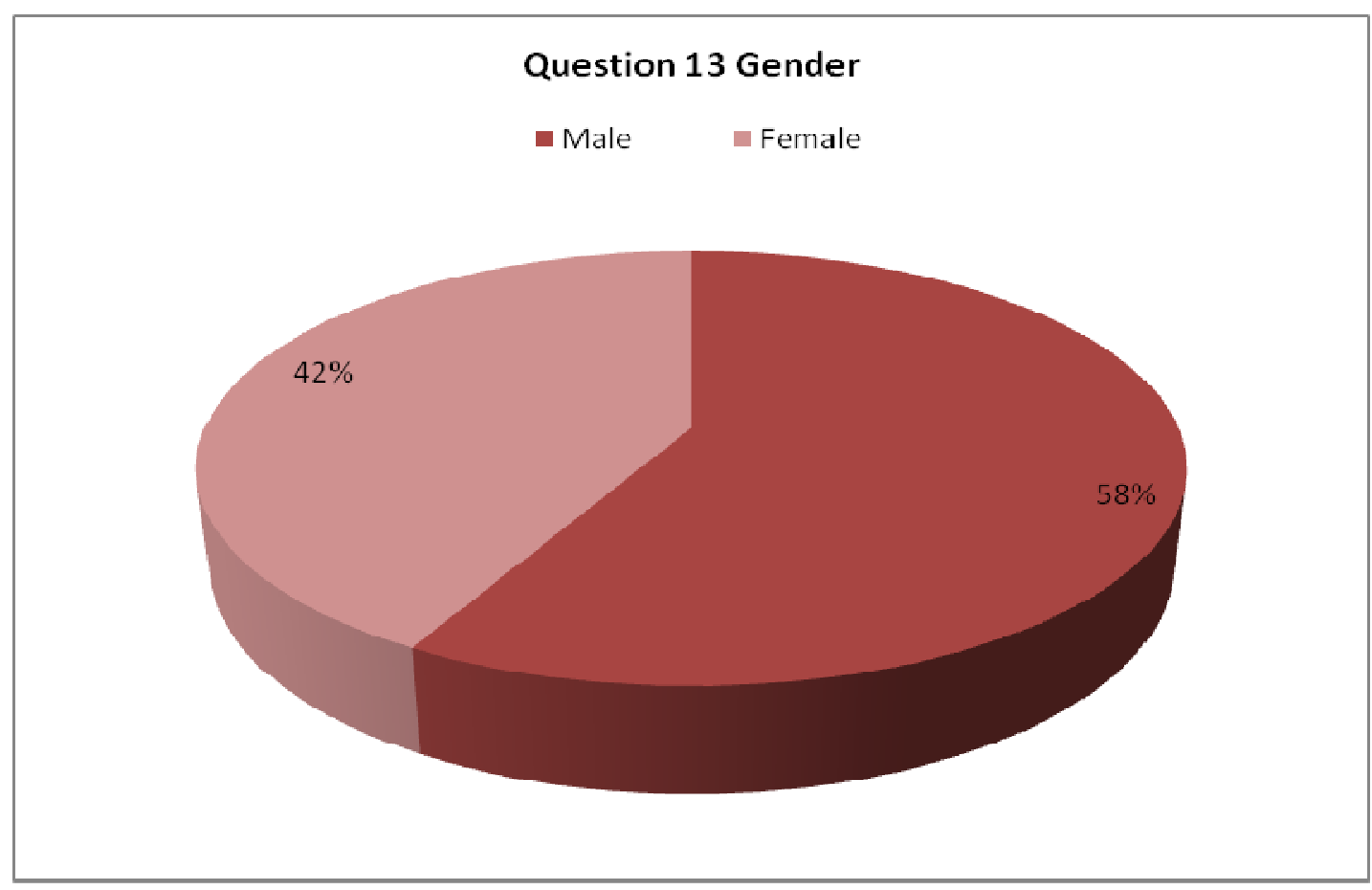




\section{APPENDIX C}

From the Chief Economist-

Ken Simonson

Associated General Contractors of America
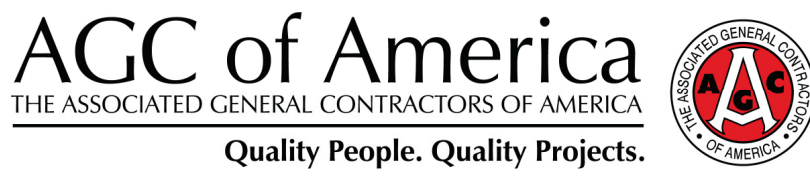

\section{Quick Facts about the Construction Industry}

The construction industry has played a powerful role in sustaining economic growth, in addition to producing structures that add to productivity and quality of life.

- Construction is a significant source of jobs. The industry provides jobs for 7.2 million employees - more than 5\% of the total nonfarm workforce. Nonresidential construction accounted for at least 4.3 million workers in August 2008. (As many as 500,000 additional specialty trade contractors may have been incorrectly counted as residential workers but are now employed in nonresidential work.)

- Construction jobs are good-paying jobs. In August 2008, seasonally adjusted hourly earnings in construction averaged $\$ 22.05$ per hour, $22 \%$ higher than the average for all private industry nonsupervisory workers, and an increase of 5\% since July 2007.

- Construction makes a disproportionately large contribution to GDP. For 11 straight quarters through mid-2008, investment in private nonresidential structures grew faster than gross domestic product (GDP). Construction spending totaled $\$ 1.14$ trillion (8.2\% of GDP) in 2007; nonresidential spending amounted to $\$ 638$ billionor $56 \%$ of total construction-and was up 16\% from 2006.

- Construction is a major purchaser of U.S. manufactured products. Shipments of construction materials and supplies in 2007 totaled $\$ 518$ billion-more than $10 \%$ of all U.S. manufacturers' shipments. Construction machinery shipments totaled $\$ 28$ billion- $8 \%$ of all machinery shipments.

- Materials costs are a major problem. From December 2003 to August 2008, the producer price index for inputs to construction jumped $44 \%$, more than double the rise in the consumer price index.

- The typical construction firm size is very small. In 2005, there were 778,000 construction firms with 6.8 million paid employees. Thus, average employment was 
less than nine per firm. More than two million additional construction firms had no paid employees-mainly self-employed individuals but also partnerships and holding companies

- Small business is big in construction. In 2005, 92\% of construction firms had fewer than 20 employees. Only $1 \%$ had 100 or more.

- Construction is a low-margin industry. The 2007 Construction Industry Annual Financial Survey, conducted by the Construction Financial Management Assn. (www.cfma.org), included responses from 756 companies. The net margin before income taxes in the latest fiscal year averaged $2.7 \%$. The median return on assets was $8.8 \%$. Internal Revenue Service figures for 2004 show that the 722,000 corporations in construction had net income (less deficit) of $\$ 47$ billion, or $3.7 \%$ of total receipts of $\$ 1.3$ trillion. That was considerably below the all-industry average margin of $4.9 \%$.

- Construction is a high-turnover industry in terms of entering and exiting firms. Census data prepared for the Office of Advocacy of the U.S. Small Business Administration shows that 101,000 of 652,000 establishments (fixed locations) with employees in 2005 (15\%) opened that year and 81,000 closed. 


\section{APPENDIX D}

\section{AGC of America $\frac{\text { THE ASSOCIATED GENERAL CONTRACTORS OF AMERICA }}{\text { Quality People. Quality Projects. }}$}

\section{The Kev Role of Construction in Georgia's Economv}

The industry employed 219,000 workers in May 2008, $5 \%$ of the state's nonfarm employment of $4,165,000$ and a decrease of $1.7 \%$ from one year before. Nationally, construction accounted for $5 \%$ of nonfarm employment but fell $5.1 \%$ over the year as homebuilding shrank.

Construction contributed \$18 billion to state GDP of \$397 billion in 2007.

Annual pay in 2006 in construction averaged $\$ 41,838,3 \%$ more than than the private sector average of $\$ 40,804$. Nationally, construction pay averaged $\$ 44,496,5 \%$ more than the national private sector average of $\$ 42,414$.

Small business is big in construction. Georgia had 22,000 construction firms in 2005 , of which $91 \%$ employed fewer than 20 workers. In addition, Georgia had 105,000 construction firms without employees, mainly sole proprietorships, in 2005.

Georgia's population grew $2.2 \%$ from July 2006 to July 2007 , 5th fastest of all states; the national growth rate was $1 \%$. Population growth affects the demand for many types of construction.
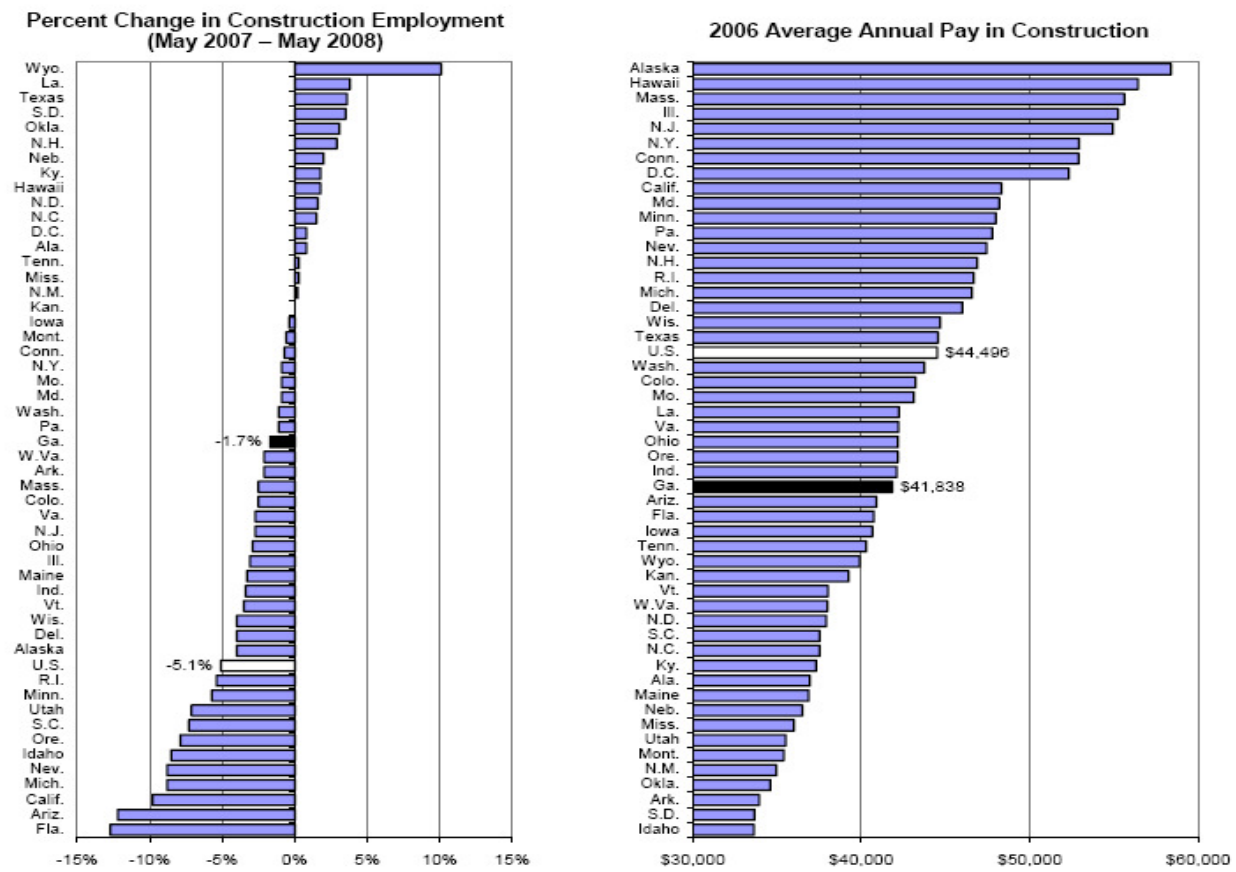

Updated: June 12,2008

Source: Ken Simonson, Chief Economist, AGC of America, simonsonk@agc.org, from U.S. government sources 


\section{APPENDIX E}

\begin{tabular}{|c|c|c|c|c|c|c|c|c|c|c|c|c|}
\hline \multicolumn{12}{|c|}{ Percentage Changes in Producer Price Indexes (PPIs) for Construction Materials and Components, 2001-2008 } & \\
\hline BLS Series ID & & \multicolumn{7}{|c|}{12 months through December-- } & \multicolumn{4}{|c|}{ to September 2008 since-- } \\
\hline & & 2001 & 2002 & 2003 & 2004 & $\underline{\underline{2005}}$ & $\underline{\underline{2006}}$ & 2007 & $\underline{8 / / 08}$ & 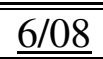 & $9 / 07$ & \multirow{5}{*}{$\begin{array}{l}18.7 \\
30.0 \\
44.8\end{array}$} \\
\hline \multicolumn{12}{|c|}{ Table 1: Changes in Consumer, Producer \& Construction Prices } & \\
\hline CUUR0000SA0 & Consumer price index (CPI-U) & 1.6 & 2.4 & 1.9 & 3.3 & 3.4 & 2.5 & 4.1 & -0.1 & 0.0 & 4.9 & \\
\hline WPUSOP3000 & Producer price index (PPI) for finished goods & -1.6 & 1.2 & 4.0 & 4.2 & 5.4 & 1.1 & 6.3 & -0.1 & -0.3 & 8.7 & \\
\hline PCUBCON & PPI for inputs to construction industries & -0.9 & 0.7 & 3.0 & 9.1 & 8.2 & 4.6 & 4.5 & 0.5 & 2.5 & 13.1 & \\
\hline PCUBHWY & $\begin{array}{l}\text { PPI for inputs to highway and street } \\
\text { construction }\end{array}$ & -3.6 & 1.0 & 2.6 & 10.8 & 14.1 & 6.2 & 9.6 & 0.7 & 3.2 & 22.2 & \multirow{5}{*}{$\begin{array}{l}75.9 \\
60.1 \\
42.6 \\
39.1 \\
33.0\end{array}$} \\
\hline PCUBHVY & PPI for inputs to other heavy construction & -2.6 & 1.0 & 2.6 & 13.4 & 8.8 & 5.5 & 6.4 & 0.2 & 1.3 & 16.9 & \\
\hline PCUBBLD & PPI for inputs to nonresidential buildings & -0.5 & 0.7 & 2.4 & 9.3 & 7.4 & 4.0 & 4.6 & 0.5 & 2.0 & 12.5 & \\
\hline PCUBRSM & PPI for inputs to multi-unit residential & -0.1 & 0.4 & 2.7 & 8.9 & 7.8 & 4.9 & 3.7 & 0.5 & 1.8 & 9.6 & \\
\hline PCUBRS1 & PPI for inputs to single-unit residential & -0.4 & 0.6 & 3.5 & 7.0 & 6.9 & 4.2 & 2.4 & 0.7 & 3.1 & 9.2 & \\
\hline \multicolumn{13}{|c|}{ Table 2: Changes in PPIs for New Buildings and Components } \\
\hline PCU236211 & New industrial building construction & \multicolumn{7}{|c|}{ not available before 2008; series began 6/07 } & 0.0 & 2.4 & 4.9 & \multirow{5}{*}{$\begin{array}{l}\text { n.a. } \\
\text { n.a. } \\
\text { n.a. } \\
\text { n.a. }\end{array}$} \\
\hline PCU236221 & New warehouse construction & not as & ailable & before & 2005 & 7.5 & 8.1 & 4.4 & -0.2 & 1.6 & 4.2 & \\
\hline PCU236222 & New school construction & \multicolumn{5}{|c|}{ not available; series began $12 / 05$} & 17.3 & 2.0 & 5.8 & 5.6 & 8.2 & \\
\hline PCU236223 & New office construction & \multicolumn{6}{|c|}{ not available; series began $6 / 06$} & 4.8 & 0.1 & 1.1 & 3.7 & \\
\hline PCU23811X & $\begin{array}{c}\text { Concrete contractors, nonresidential building } \\
\text { work }\end{array}$ & \multicolumn{7}{|c|}{ not available; series began $12 / 07$} & 0.0 & 1.3 & n.a. & \\
\hline PCU23816X & $\begin{array}{l}\text { Roofing contractors, nonresidential building } \\
\text { work }\end{array}$ & \multicolumn{7}{|c|}{ not available; series began $12 / 07$} & 1.5 & 3.9 & n.a. & \multirow{2}{*}{$\begin{array}{l}\text { n.a. } \\
\text { n.a. }\end{array}$} \\
\hline PCU23821X & $\begin{array}{l}\text { Electrical contractors, nonresidential building } \\
\text { work }\end{array}$ & \multicolumn{7}{|c|}{ not available; series began $12 / 07$} & 1.0 & 1.5 & n.a. & \\
\hline
\end{tabular}




\section{Table 2: Changes in PPIs for New Buildings and Components Continued}

\begin{tabular}{|c|c|c|c|c|c|c|c|c|c|c|c|c|}
\hline PCU23822X & $\begin{array}{l}\text { Plumbing contractors, nonresidential building } \\
\text { work }\end{array}$ & \multicolumn{7}{|c|}{ not available; series began $12 / 07$} & 1.5 & 2.8 & n.a. & n.a. \\
\hline \multicolumn{13}{|c|}{ Table 3: Changes in PPIs for Specific Construction Inputs } \\
\hline WPU057303 & \#2 diesel fuel & 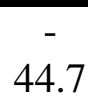 & 54.4 & 13.0 & 37.9 & 46.7 & 2.3 & 33.9 & -1.4 & $\begin{array}{c}- \\
18.7\end{array}$ & 39.0 & 248.8 \\
\hline WPU05810112 & Asphalt (at refinery) & \multicolumn{2}{|c|}{$\begin{array}{c}\text { not } \\
\text { available }\end{array}$} & 10.0 & 18.3 & 17.8 & 34.9 & 5.8 & 6.2 & 55.8 & 129.8 & 402.4 \\
\hline WPU139401 & Asphalt paving mixtures and blocks & 0.9 & 2.0 & 3.7 & 4.3 & 14.3 & 27.6 & 1.3 & 3.1 & 29.5 & 51.2 & 135.3 \\
\hline WPU136 & Asphalt felts and coatings & 4.6 & -0.6 & 6.3 & 4.1 & 15.3 & 5.0 & -2.5 & 4.9 & 32.4 & 51.6 & 88.8 \\
\hline WPU1361 & $\begin{array}{c}\text { Prepared asphalt } \& \text { tar roofing \& siding } \\
\text { products }\end{array}$ & 5.0 & -1.7 & 5.3 & 4.6 & 16.2 & 5.2 & -2.4 & 6.1 & 28.3 & 47.5 & 85.5 \\
\hline WPU133 & Concrete products & 2.5 & -0.3 & 1.5 & 7.6 & 10.1 & 8.1 & 3.3 & 0.8 & 0.8 & 4.3 & 37.5 \\
\hline WPU1331 & Concrete block and brick & 2.3 & 1.6 & 3.2 & 4.7 & 8.1 & 6.8 & 3.2 & 0.8 & 1.3 & 3.8 & 29.5 \\
\hline WPU1332 & Concrete pipe & 4.4 & 1.7 & 1.4 & 5.5 & 7.5 & 2.5 & 1.1 & -0.1 & 0.6 & 12.5 & 34.0 \\
\hline WPU1333 & Ready-mixed concrete & 2.5 & -1.1 & 1.1 & 8.7 & 11.3 & 10.1 & 3.3 & 1.2 & 0.8 & 3.3 & 41.2 \\
\hline WPU1334 & Precast concrete products & 0.7 & 0.3 & 2.5 & 6.0 & 6.0 & 4.7 & 4.8 & -0.1 & 0.1 & 4.5 & 28.9 \\
\hline WPU1335 & Prestressed concrete products & 5.3 & 1.8 & -0.2 & 8.2 & 14.3 & 4.9 & 1.2 & -1.0 & 2.5 & 4.9 & 38.4 \\
\hline WPU1342 & Brick and structural clay tile & 5.3 & 1.9 & 0.7 & 3.0 & 9.4 & 6.0 & -0.2 & -0.2 & 0.6 & -0.3 & 19.4 \\
\hline WPU072106 & Plastic construction products & -2.7 & 3.1 & 3.2 & 7.2 & 21.6 & -0.7 & 0.3 & 0.8 & 3.6 & 6.8 & 37.6 \\
\hline WPU137 & Gypsum products & 0.4 & 3.4 & 2.8 & 20.0 & 18.8 & 5.5 & 22.2 & -1.7 & 4.2 & 1.7 & 22.2 \\
\hline WPU1392 & Insulation materials & 0.4 & -1.5 & 2.0 & 8.6 & 2.6 & 2.1 & -3.3 & -0.2 & 1.2 & -1.8 & 9.3 \\
\hline WPUSI004011 & Lumber and plywood & -2.9 & 1.4 & 13.1 & 5.0 & -1.1 & $\overline{10.8}$ & -1.3 & 0.1 & -1.8 & -3.4 & -7.3 \\
\hline WPU062101 & Architectural coatings & 2.9 & 0.6 & 3.9 & 5.3 & 9.2 & 6.3 & 4.1 & 1.0 & 8.0 & 12.2 & 42.8 \\
\hline
\end{tabular}




\begin{tabular}{|c|c|c|c|c|c|c|c|c|c|c|c|c|}
\hline \multicolumn{13}{|c|}{ Table 3: Changes in PPIs for Specific Construction Inputs Continued } \\
\hline WPU1017 & Steel mill products & -6.1 & 11.1 & 1.7 & 48.8 & -3.8 & 11.6 & 1.0 & -3.6 & 0.3 & 38.2 & 122.4 \\
\hline WPU101704 & Hot-rolled bars, plates, \& structural shapes & -4.3 & 2.1 & 11.3 & 53.8 & -1.0 & 7.5 & 8.1 & -4.4 & 4.0 & 37.7 & 144.0 \\
\hline WPU101706 & Steel pipe and tube & -3.7 & 9.1 & 3.3 & 66.0 & 1.2 & 5.5 & -1.9 & -1.0 & 4.1 & 36.8 & 140.3 \\
\hline WPU102502 & Copper and brass mill shapes & -9.5 & -1.6 & 11.6 & 29.6 & 31.0 & 44.4 & -3.8 & -9.0 & -8.4 & -2.9 & 142.6 \\
\hline WPU102501 & Aluminum mill shapes & -2.9 & -0.9 & -0.5 & 9.9 & 5.0 & 12.7 & -1.7 & -2.8 & -1.7 & 4.1 & 34.3 \\
\hline WPU1073 & Sheet metal products & -0.8 & 2.0 & 0.6 & 15.2 & 0.4 & 6.5 & 0.4 & 0.8 & 3.2 & 10.7 & 36.7 \\
\hline WPU107405 & Fabricated structural metal & -1.3 & -2.4 & 0.1 & 24.7 & 2.8 & 3.6 & 5.3 & 0.0 & 2.9 & 17.6 & 62.5 \\
\hline WPU10740501 & Fabricated structural metal for buildings & -1.5 & -3.3 & -0.1 & 20.0 & 3.1 & 3.3 & 4.7 & -0.1 & 1.8 & 13.9 & 51.4 \\
\hline WPU107408 & Architectural and ornamental metalwork & -0.1 & 3.7 & 0.7 & 23.5 & 3.1 & 4.9 & 2.8 & 6.5 & 12.3 & 24.6 & 69.3 \\
\hline WPU107409 & Fabricated iron \& steel pipe, tube, \& fittings & 0.6 & 0.1 & 1.2 & 32.6 & 5.5 & -2.8 & -1.6 & 1.4 & 6.7 & 15.2 & 53.0 \\
\hline WPU1076 & Fabricated steel plate & 0.6 & -1.0 & 0.6 & 7.6 & 0.6 & 8.6 & 9.9 & 7.2 & 9.3 & 32.9 & 59.8 \\
\hline WPU1079 & Prefabricated metal buildings & 0.0 & 4.0 & -0.7 & 35.5 & 2.0 & 5.5 & 1.8 & 0.9 & 4.1 & 29.7 & 92.8 \\
\hline WPU112 & Construction machinery and equipment & -0.1 & 1.9 & 1.3 & 6.0 & 4.9 & 3.6 & 2.2 & 0.5 & 1.4 & 3.9 & 21.7 \\
\hline \multicolumn{13}{|c|}{ Table 4: Changes in PPIs for Basic Inputs Important to Construction } \\
\hline WPU056 & Crude petroleum (domestic production) & $\begin{array}{c}- \\
42.4\end{array}$ & 60.6 & 14.3 & 30.5 & 49.6 & 0.1 & 52.4 & -9.0 & $\begin{array}{c}- \\
20.1\end{array}$ & 35.9 & 250.1 \\
\hline WPU0553 & Industrial natural gas & $\begin{array}{c}- \\
36.7 \\
\end{array}$ & 12.2 & 20.3 & 20.1 & 31.5 & $\begin{array}{c}- \\
13.2\end{array}$ & -4.6 & -6.7 & -9.4 & 27.4 & 53.4 \\
\hline WPU066 & Plastic resins and materials & -9.8 & 9.2 & 6.4 & 28.6 & 10.8 & -7.8 & 10.0 & -3.1 & 7.3 & 19.2 & 63.9 \\
\hline WPU1321 & Construction sand/gravel/crushed stone & 3.3 & 2.5 & 2.4 & 4.3 & 7.7 & 9.3 & 8.6 & 0.2 & 1.6 & 6.9 & 41.0 \\
\hline WPU1322 & Cement & 1.0 & 1.3 & -1.1 & 7.9 & 12.2 & 10.5 & 3.5 & -1.0 & -1.6 & -1.7 & 38.3 \\
\hline WPU1011 & Iron ore & 1.5 & -1.3 & 1.6 & 6.7 & 15.5 & 7.5 & 1.3 & 0.0 & 0.0 & 12.0 & 50.5 \\
\hline WPU1012 & Iron and steel scrap & -5.6 & 27.8 & 64.9 & 50.8 & $\begin{array}{c}- \\
10.8\end{array}$ & 2.9 & 30.4 & $\begin{array}{c}- \\
22.4\end{array}$ & 21.3 & 47.9 & 159.8 \\
\hline WPU101212 & Stainless and alloy steel scrap & \multicolumn{6}{|c|}{ no data from 1996 until September 2006} & -7.7 & 1.6 & -4.6 & -5.4 & n.a. \\
\hline WPU102102 & Copper ores & $\begin{array}{c}- \\
19.6\end{array}$ & 3.6 & 37.4 & 65.1 & 39.3 & 53.1 & -0.9 & $\begin{array}{c}- \\
10.4\end{array}$ & -5.6 & -5.2 & 293.7 \\
\hline
\end{tabular}


Table 4: Changes in PPIs for Basic Inputs Important to Construction Continued

\begin{tabular}{|c|c|c|c|c|c|c|c|c|c|c|c|c|}
\hline \multicolumn{13}{|c|}{ Table 4: Changes in PPIs for Basic Inputs Important to Construction Continued } \\
\hline WPU102301 & Copper base scrap & $\overline{17.4}$ & 11.2 & 30.7 & 34.5 & 51.9 & 50.0 & 1.2 & -4.6 & -7.8 & 4.2 & \multirow{3}{*}{244.9} \\
\hline \multicolumn{12}{|c|}{ Updated 10/16/08 Source: Bureau of Labor Statistics (BLS): www.bls.gov/cpi for CPI, www.bls.gov/ppi for PPIs } & \\
\hline Compiled b & n (simonsonk@agc. & nomis & Asso & iated & eneral & Contra & tors of & $\Delta \mathrm{mer}$ & & & & \\
\hline
\end{tabular}




\section{APPENDIX F}

Skanska Preconstruction Phase Roles and Responsibilities

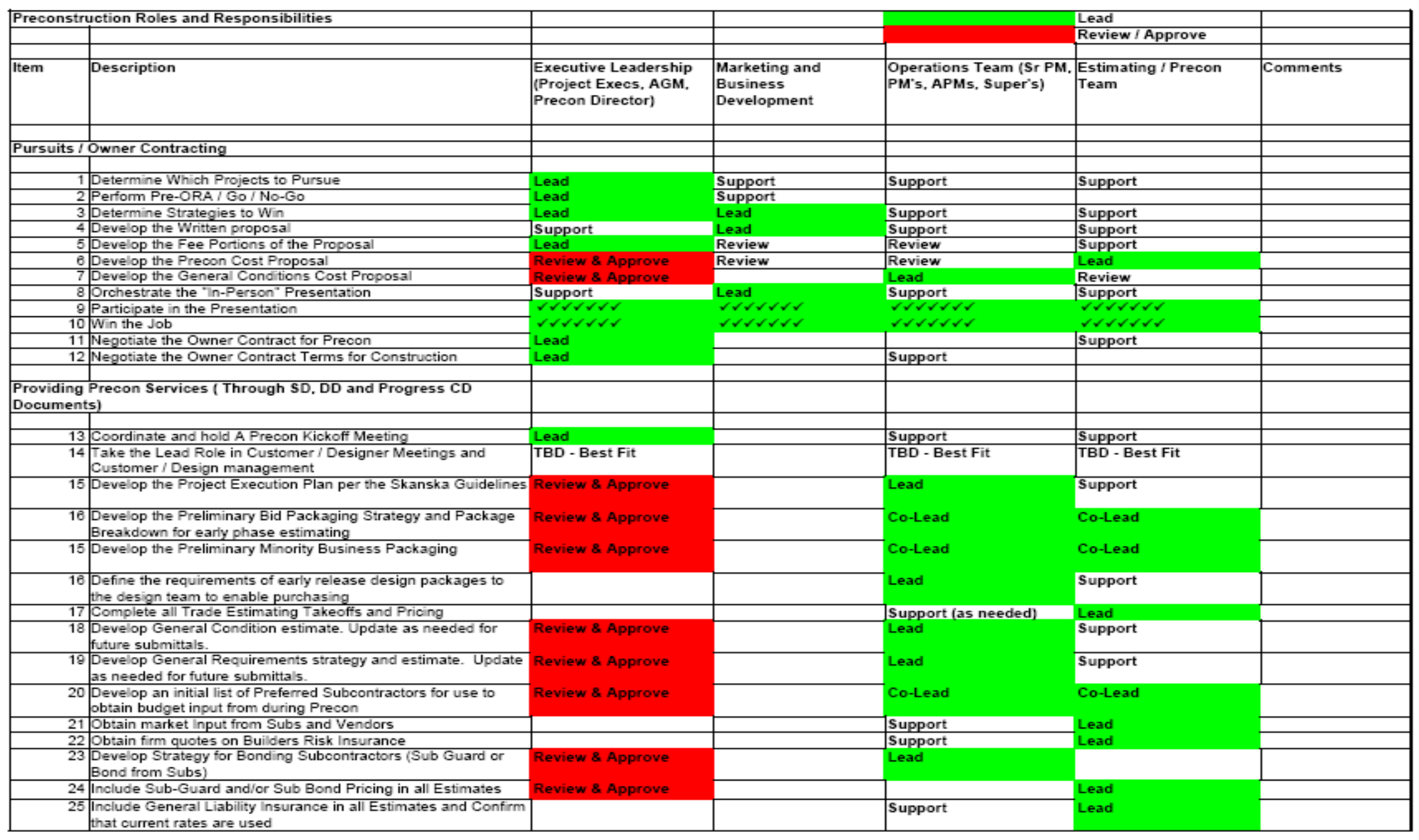


Skanska Preconstruction Phase Roles and Responsibilities Continued

\begin{tabular}{|c|c|c|c|c|c|c|}
\hline \multicolumn{2}{|c|}{ Preconstruction Roles and Responsibilities } & & & & Lead & \\
\hline & & & & & Review/Approve & \\
\hline Item & Description & $\begin{array}{l}\text { Executive Leadership } \\
\text { (Project Execs, AGM. } \\
\text { Precon Director) }\end{array}$ & $\begin{array}{l}\text { Marketing and } \\
\text { Business } \\
\text { Development }\end{array}$ & $\begin{array}{l}\text { Operations Team (Sr PM, } \\
\text { PM's, APMs, Super's) }\end{array}$ & $\begin{array}{l}\text { Estimating / Precon } \\
\text { Team }\end{array}$ & Comments \\
\hline 28 & $\begin{array}{l}\text { Verify contingency is carried from the initial estimate through } \\
\text { the final estimates, considering a budget for design/estimating } \\
\text { contingency and construction contingency. No change to this } \\
\text { figure without approval from Executive Management }\end{array}$ & Review \& Approve & & Support & Lead & \\
\hline 27 & $\begin{array}{l}\text { Verify escalation is budgeted for, from the initial estimate } \\
\text { through the final estimate. No change to this figure without } \\
\text { approval from Executive Management }\end{array}$ & Review \& Approve & & Support & Lead & \\
\hline 28 & $\begin{array}{l}\text { Develop and Complete all Estimate Reports including the } \\
\text { Technical Clarifications }\end{array}$ & Review \& Approve & & Support & Lead & \\
\hline 29 & $\begin{array}{l}\text { Review and offer suggestions on all Technical Clarifications that } \\
\text { are developed during the Submittal of Costs. }\end{array}$ & Review \& Approve & & Lead & & \\
\hline 30 & Presentation of Estimates and Reports to Customers & Review \& Approve & & Support & Lead & \\
\hline 31 & $\begin{array}{l}\text { Develop Value Management Options, Price Options, Evaluate } \\
\text { Options, Present Options to Owner }\end{array}$ & Review \& Approve & & Support & Lead & \\
\hline 32 & $\begin{array}{l}\text { Develop a list of potential VE's and forward to PreCon to be } \\
\text { included in their VE Presentation (note that Precon is } \\
\text { developing list - see item } 34 \text { above) }\end{array}$ & & & Lead & Support & \\
\hline 33 & $\begin{array}{l}\text { Track the Value Management Options (PCE Log) from On-set } \\
\text { to incorporation into the design documents }\end{array}$ & & & Support & Lead & \\
\hline 34 & $\begin{array}{l}\text { Request and monitor all Owner Design Comments for scope } \\
\text { increase, schedule affects using the PCE Log Process }\end{array}$ & & & Support & Lead & \\
\hline 35 & $\begin{array}{l}\text { Perform a detailed analysis of scope changes with each new } \\
\text { set of drawings }\end{array}$ & & & Support & Lead & \\
\hline 36 & $\begin{array}{l}\text { Develop presentation of these scope increases to the Owner } \\
\text { and Architect }\end{array}$ & & & Support & Lead & \\
\hline 37 & $\begin{array}{l}\text { Develop a detailed "Constructability Review" and track the } \\
\text { items from On-set to incorporation into the design documents }\end{array}$ & & & Lead & Support & \\
\hline 38 & $\begin{array}{l}\text { Develop and Maintain the Project schedule inclusive of al } \\
\text { Precon and Construction activities }\end{array}$ & Review \& Approve & & Lead & Support & \\
\hline 39 & Develop presentation and lead 3rd party reconciliation process & & & Support & Lead & \\
\hline 40 & $\begin{array}{l}\text { Coordinate through the design team, separate meetings with } \\
\text { the design architects consultants (Structural, PM\&E) to confirm } \\
\text { scope understanding and budget compliance }\end{array}$ & & & Co-Lead & Co-Lead & \\
\hline 41 & Attend Owner Facility Staff Review Meetings & & & 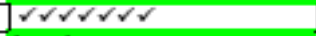 & Davavava & \\
\hline 42 & $\begin{array}{l}\text { Develop and maintain Site Logistics Plan and insure } \\
\text { coordination of same with owner and with the Design } \\
\text { Documents }\end{array}$ & Review \& Approve & & Lead & Support & \\
\hline 43 & Develop and maintain Site Safety Plan & Review \& Approve & & Lead & Support & \\
\hline Subcontra & actor Prequalifications & & & & & \\
\hline & & & & & & \\
\hline 44 & $\begin{array}{l}\text { Overall Leadership of Prequal fication Process - Determine } \\
\text { Acceptability for Bidding and Sub-Guard Program }\end{array}$ & & & Lead & Support & \\
\hline
\end{tabular}


Skanska Preconstruction Phase Roles and Responsibilities Continued

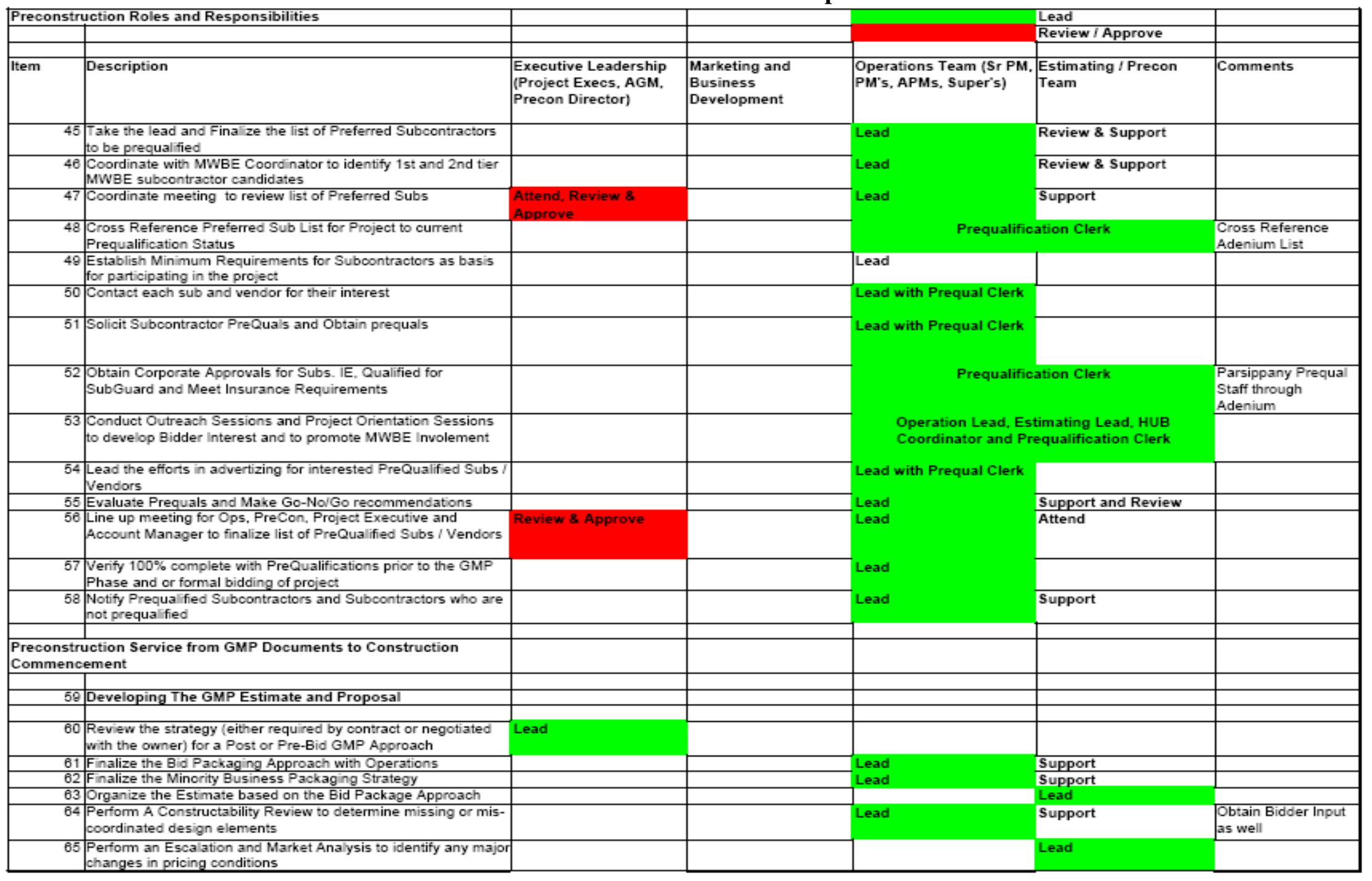


Skanska Preconstruction Phase Roles and Responsibilities Continued

\begin{tabular}{|c|c|c|c|c|c|c|}
\hline \multicolumn{2}{|c|}{ Preconstruction Roles and Responsibilities } & & & & \multirow{2}{*}{$\begin{array}{l}\text { Lead } \\
\text { Review / Approve }\end{array}$} & \\
\hline & & & & & & \\
\hline Item & Description & $\begin{array}{l}\text { Executive Leadership } \\
\text { (Project Execs, AGM, } \\
\text { Precon Director) }\end{array}$ & $\begin{array}{l}\text { Marketing and } \\
\text { Business } \\
\text { Development }\end{array}$ & $\begin{array}{l}\text { Operations Team (Sr PM, } \\
\text { PM's, APMs, Super's) }\end{array}$ & $\begin{array}{l}\text { Estimating / Precon } \\
\text { Team }\end{array}$ & Comments \\
\hline 86 & Complete and submit the GMP Review Memo & Review \& Approve & & Support and Review & Lead & \\
\hline 67 & Schedule and Hold a Peer Review when required & Lead & & Support & Support & \\
\hline 68 & $\begin{array}{l}\text { Pre-Bid GMP Approach (Develop the GMP, then Bid the } \\
\text { work) }\end{array}$ & & & & & $\begin{array}{l}\text { This apporoach } \\
\text { unique to NC Office }\end{array}$ \\
\hline 69 & Develop Scopes of Work for Each Major Bid Package & & & Lead & Support & \\
\hline 70 & $\begin{array}{l}\text { Review Scopes of Work for Consistency with Estimating to } \\
\text { Date }\end{array}$ & & & Support & Lead & \\
\hline 71 & Obtain Subcontractor Input for Pricing Structure & & & Support & Lead & \\
\hline 72 & $\begin{array}{l}\text { Obtain no less then } 2 \text { complete subcontractor "budget" } \\
\text { proposals in all trades }\end{array}$ & & & Co-Lead & Co-Lead & \\
\hline 73 & $\begin{array}{l}\text { Insure Sub Input and Estimate reflect the requirements of the } \\
\text { Scope of Work }\end{array}$ & & & Support & Lead & \\
\hline 74 & $\begin{array}{l}\text { Develop the GMP Report and Associated Clarifications, } \\
\text { Exclusions, Allowances and Document Log }\end{array}$ & & & Support & Lead & \\
\hline 75 & Review the GMP Report and Provide Comments & Review & & Lead & & \\
\hline 76 & Approve the GMP Submission to the Customer & Review \& Approve & & Support & & \\
\hline 77 & Proceed to ltem 82 below & & & & & \\
\hline & & & & & & \\
\hline 78 & $\begin{array}{l}\text { Post-Bid GMP Approach (Bid the Work to Establish the } \\
\text { GMP) }\end{array}$ & & & & & \\
\hline 79 & Develop Scopes of Work for Each Major Bid Package & & & Lead & Support & \\
\hline 80 & $\begin{array}{l}\text { Review Scopes of Work for Consistency with Estimating to } \\
\text { Date }\end{array}$ & & & Support & Lead & \\
\hline 81 & $\begin{array}{l}\text { Obtain no less then } 3 \text { complete subcontractor proposals in all } \\
\text { trades }\end{array}$ & & & Co-Lead & Co-Lead & $\begin{array}{l}\text { Possible Co-Lead. } \\
\text { Consider Available } \\
\text { Resources }\end{array}$ \\
\hline 82 & $\begin{array}{l}\text { Develop the Bid Package inclusive of Invitation to Bid, } \\
\text { Instructions to Bidders, RFP Form of Proposal, Contract } \\
\text { Documents, etc. Finalize all amendments and exhibits to our } \\
\text { contract to include in the Bid Packages }\end{array}$ & Review \& Approve & & Lead & Review as Requested & \\
\hline 83 & Finalize Scope of Work for Each Bid Package & Review \& Approve & & Lead & Review & \\
\hline 84 & $\begin{array}{l}\text { Lead the efforts in sending out the Bid Package Documents to } \\
\text { each bidder }\end{array}$ & & & Lead & & $\begin{array}{l}\text { Possible Co-Lead. } \\
\text { Consider Available } \\
\text { Resources }\end{array}$ \\
\hline 85 & Conduct the Pre-Bid Meetings & & & Lead & Attend as Requested & \\
\hline 88 & Control, Manage and Issue all bid clarifications / addendum & & & Lead & Review & $\begin{array}{l}\text { Possible Co-Lead. } \\
\text { Consider Available } \\
\text { Resources }\end{array}$ \\
\hline 87 & $\begin{array}{l}\text { Perform phone calls weekly to each subcontractor bidding } \\
\text { within each package }\end{array}$ & & & Lead & Support & $\begin{array}{l}\text { Possible Co-Lead. } \\
\text { Consider Available } \\
\text { Resources }\end{array}$ \\
\hline 88 & Schedule and run/manage the bid openings & & & Lead & Attend as Requested & \\
\hline 89 & Prepare certified bid tabs for each opening & & & Lead & Review & \\
\hline
\end{tabular}


Skanska Preconstruction Phase Roles and Responsibilities Continued

\begin{tabular}{|c|c|c|c|c|c|c|}
\hline \multicolumn{2}{|c|}{ Preconstruction Roles and Responsibilities } & & & & \multirow{2}{*}{\begin{tabular}{|l} 
Lead \\
Review / Approve \\
\end{tabular}} & \\
\hline & & & & & & \\
\hline Item & Description & $\begin{array}{l}\text { Executive Leadership } \\
\text { (Project Execs, AGM, } \\
\text { Precon Director) }\end{array}$ & $\begin{array}{l}\text { Marketing and } \\
\text { Business } \\
\text { Development }\end{array}$ & $\begin{array}{l}\text { Operations Team (Sr PM, } \\
\text { PM's, APMs, Super's) }\end{array}$ & $\begin{array}{l}\text { Estimating / Precon } \\
\text { Team }\end{array}$ & Comments \\
\hline 200 & $\begin{array}{l}\text { Develop detailed Scope Analysis Worksheets for each bid } \\
\text { package }\end{array}$ & Review \& Approve & & Lead & $\begin{array}{l}\text { Review and Assist as } \\
\text { Requested }\end{array}$ & \\
\hline $91 \mid \begin{array}{l}0 \\
F\end{array}$ & $\begin{array}{l}\text { Conduct Subcontractor Scope Interviews (Phone and Face to } \\
\text { Face) }\end{array}$ & & & Lead & $\begin{array}{l}\text { Review and Assist as } \\
\text { Requested }\end{array}$ & Co-Lead \\
\hline $92{ }_{5}^{0}$ & $\begin{array}{l}\text { Obtain Revised Subcontractor Cost information as a result of } \\
\text { scope reviews }\end{array}$ & & & Lead & & Co-Lead \\
\hline $93 \mid \begin{array}{ccc}93 \\
0 \\
c\end{array}$ & $\begin{array}{l}\text { Develop and Maintain the Procurement Log identifying for each } \\
\text { bid package, the budget amount, contract amount, variance, } \\
\text { comments }\end{array}$ & Review & & Lead & Review and Comment & \\
\hline $94 \mathrm{P}$ & Prepare Subcontracts for Execution & Review \& Approve & & Lead & & \\
\hline 950 & Obtain Executed Subcontracts & & & Lead & & \\
\hline $96\left[\begin{array}{l}D \\
E\end{array}\right.$ & $\begin{array}{l}\text { Develop the GMP Report and Associated Clarifications, } \\
\text { Exclusions, Allowances and Document Log }\end{array}$ & & & Support & Lead & \\
\hline $97 \mathbb{R}$ & Review the GMP Report and Provide Comments & Review & & Lead & Review \& Comment & \\
\hline $98 \mathrm{~A}$ & Approve the GMP Submission to the Customer & Review \& Approve & & Support & & \\
\hline & & & & & & \\
\hline
\end{tabular}

Source: Skanska USA Building Inc. 


\section{REFERENCES}

Barry Benator and Albert Thumann. "Project Management \& Leadership Skills for Engineering \& Construction Projects," p1-10, 2006

Birnberg Howard, "Project Management for Building Designers and Owners", p18-30, 1999

David L. Cleland, “Project Manager's Handbook, p88-90, 2008

Eric Verzuh, "The Fast Forward MBA in Project Management”, P 5-20, 2008

Gregory A. Howell, Hal Macomber Lauri Koskela3 and John Draper, "Leadership and Project Management: time for a shift from fayol to flores", 2006

Howard G. Birberg, "Project Mangement for Building Designers and Owners", 1999

James M. Kouzes, "The Leadership Challenge: How to Keep Getting Extraordinary Things Done in Organizations", 2007

James Tayler, “A Survival Guide for Project Management”, p13-17, 2006

James P. Lewis, "Fundamentals of Project Management", p 28-30, 2007

Kevin Eikenberry, "Four Answers about Leadership", 2007

(http://www.sideroad.com/Leadership/leadership-characteristic.html, September, 2008)

Larry Richman, “Improving Your Project Management Skills”, p18-28, 2006

Maslen, P.E. and Gordon, M. Head., Chem. Phys. Lett. 283, 102 (1998)

Milton D. Rosenau, "Successful Project Management”, 1998 
Organizational Leadership Development: Personal Resources Handbook, Environmental Health, Seattle-King County Department of Public Health, January, p. 21-26, 1999

Project Management Institute, "A Guide to the Project Management Body of Knowledge (PMBOK® Guide) - Third Edition”, p37-51, 2004

Punch, K. F. (2003). Survey Research: The Basics. London: Sage Publications Ltd.

Robert Slater, "Jack Welch and the GE Way: Management Insights and Leadership Secrets of the Legendary CEO", 1998

Sidney M. Levy, "Project Management in Construction”, p2-5, 1994

Sheehan, K. "E-mail Survey Response Rates: a Review". "Journal of Computer-Mediated Communication", 2001

http://www.agc.org/ August, 2008 